\title{
Political Science and the Democratic Method: \\ How Higher Education Can Strengthen Democracy
}

By Titus Alexander, FRSA

Crick Centre, University of Sheffield, UK.

\begin{abstract}
Liberal democracies face competition from authoritarian models of government such as China as well as internal challenges. This paper proposes a theoretical and methodological approach for political science to improve the effectiveness of democratic governance through civic education and engagement. I suggest that every state can be seen as an experiment in political science and a working model or hypothesis of how to govern, developed over centuries through trial and error. All institutions can be seen as social experiments, embodying collective knowledge of how to deal with an aspect of society. Drawing on theories of reflexivity, this insight provides a theoretical basis for scholars to help citizens address democratic deficits and improve pluralistic politics as a method for solving problems in society. Treating institutions as experiments also gives scholars new ways to increase effectiveness of research and civic engagement, described in Part 2. Part 3 outlines existing models from across the world to illustrate seven levels of support for civic engagement that could be developed to strengthen pluralistic democracy as an effective alternative to authoritarianism. The paper concludes with three strategies for a large-scale experimental programme to support citizens improving democracy as a model of government and method for solving social problems.
\end{abstract}

DRAFT 15: This is a work in progress. Your comments will make this paper more useful by helping to clarify the argument and exposing flaws.

I welcome suggestions for where and how this argument can be discussed, presented or published to inform action: strengthening democracy is not an academic exercise.

Please email Titus.Alexander@mcr1.poptel.org.uk with feedback

* in the text means supporting references could be added if necessary.

\section{Introduction}

A century of political science and civic engagement by American universities has not stopped the erosion of democratic values and trust in politics. The storming of the United States Capitol on 6 January 2021, systematic undermining of democratic norms under President Trump, and widespread rejection of evidence as "fake news" by large sections of the American public, raises challenging questions about the American model of democracy and the civic education of its citizens. The Trump presidency was a symptom of deeper problems, reflected in widespread dissatisfaction with political systems across Europe, India, Turkey and Brazil as well as in the US. Democratic societies throughout the world face immense challenges. Social 
and political scientists, and their universities, have a responsibility to help their fellow citizens find better solutions.

This paper aims to provide theoretical and empirical support for universities to be more ambitious about addressing weaknesses in our democratic systems through social research and support for civic engagement. This first part summarises why this matters, then aims to show that institutions are social experiments and the equivalent of theories in the physical sciences, embodying collective knowledge about how to deal with aspects of social reality. This means that improving the ability of institutions to achieve social outcomes should become a central task for social and political sciences. Because citizens have a decisive role in society, democratic politics are a form of peer review with a critical role in deciding public policy, able to accept or reject propositions for government at any level. Part two explores the implications of this argument for teaching civic engagement, arguing that it has to be a two-way street, in which professionals work with citizens to address democratic deficits. It uses Pippa Norris's model to focus on three priority areas. Part three outlines seven levels of institutional models in higher education that support civic engagement, as a framework for concerted experiments in how to improve democratic governance. The conclusion suggests three strategies for higher education to develop civic engagement at scale, equivalent to the Manhattan Project, Apollo moon programme and global race for a Covid19 vaccine, to enable all citizens to have an effective voice in solving problems and creating a better world.

\section{Why this matters: challenges, roles and responsibilities}

Universities' potential to strengthen democratic effectiveness and participation may be their most important role in the coming decade. The challenges of global heating, Black Lives Matter, Me Too, healthcare, poverty, migration, nuclear weapons, terrorism and many other critical issues urgently need durable political solutions. * Dissatisfaction with democratic politics also means that citizens in many countries are attracted to authoritarian leaders and systems (Dean 2019; Keane 2020; Mudde; 2019; Norris and Inglehart 2018). Terrorist attacks 
by militant Islamicists and right-wing extremists, as well as Covid19, have led governments to curb freedoms and increase surveillance. * Democratic governance of the United States has become more narrowly authoritarian and nationalistic (Halper \& Clark 2005; Lieven 2012; Levitsky \& Ziblatt 2019). Meanwhile, China's rise as an economic and technological superpower offers developing countries a successful alternative to liberal democracy (Mahbubani 2020).

Throughout this paper I will contrast the modern Chinese model with liberal democracy because it offers a credible alternative. It is deeply embedded in the world's economy, governance and physical infrastructure, and the future of humanity depends on citizens of all countries understanding each other and governing our shared planet together. Education for civic engagement needs to improve the ability of citizens to understand alternative models of governance and take part in global governance as much as local or national politics.

In this context, political scientists cannot be bystanders, chronicling the decay of democracy and trials or triumphs of authoritarianism. But nor should we be partisans, promoting one political faction, party, country, regime or even political philosophy. Pluralism of thought, academic freedom, openness to challenge and recognition of fallibility are core principles that enable both science and democracy to flourish. * Neither science nor democracy are perfect. I hope to show that pluralistic democracy itself is a vital method for social sciences to help humanity improve conditions for everyone. Innovation and improvement of governance at all levels has the potential to unlock people's ability to solve collective problems and create sustainable prosperity for all. To do this, political scientists have a responsibility to equip citizens - including leaders, practitioners and lay people - with confidence, knowledge and to make democracy work better for everyone.

\section{Part 1}

\section{Ideas: institutions as social experiments}


The theoretical argument has four parts. First, every institution is a proto-scientific experiment in how to solve social problems, whose success or failure is tested in practice. Second, institutions, and societies as a whole, are reflexive, shaped by people who are influenced by ideas as well as experience. Third, because institutions are reflexive, they embody collective thinking and experience about how to deal with their areas of concern and can be seen as working models or 'social theories', equivalent to hypothesis and theories in the natural sciences. Fourth, open societies in which people are free to express themselves, organise, and challenge those in power, have greater reflexivity than closed or authoritarian societies. This gives them the potential to create more responsive, resilient and effective institutions, thus better models for dealing with social problems. This may be seen as an evolving "democratic method" for evaluating natural experiments in government and society. The following sections explore each of these four points in more depth.

\subsection{Institutions as experiments in social sciences}

The first point is straightforward. Every institution can be seen as an experiment in how to achieve multiple social outcomes. For the purposes of this paper, an institution is any regular pattern of behaviour among people that continues over time. This is a simpler definition than most theories, closer to that of new institutionalism (Lowndes \& Roberts 2013; Peters 2019) and more like Samuel Huntington's "stable, valued, recurring patterns of behavior" (1996:9). It includes informal institutions, such as social norms, honour codes, networks of influence, and relationships of caste or faith that continue over time and affect social outcomes, as well as micro-institutions, such as processes for appointing, managing or dismissing people, and mini-institutions, such as a department, course or project. This broad definition recognises that informal institutions - such as membership of a faith or secret society; systematic discrimination on grounds of gender, race or age; presenteeism at work (Hemp 2004), or guanxi (connections) in China (Yanjie 2018) - have a powerful but often unspoken role in formal institutions. Micro-institutions, like rituals, routines, checklists, job interview processes and election procedures, play a decisive part in all institutions. Mini-institutions include any 
recurring programme of activities or administrative units designed to achieve objectives within a larger institution, such as a course programme, conference or research network. Some deep institutions, like language, markets, money or social bonding, are embedded into the fabric of most societies and constantly evolve to meet changing needs.*

Everyday social experiments have multiple variables and rarely have control groups, but they provide most evidence by which we live our lives and run our societies. People learn from social experiments. De Tocqueville's Democracy in America (1835) made the United States a model for people seeking an alternative to aristocratic or colonial rule. In the $20^{\text {th }}$ century the Soviet model inspired millions, including China's Communist Party. More recently Taiwan and Singapore were models for Deng Xiaoping's market reforms in China after 1978, * which in turn influenced many other countries.* The collapse of the Soviet Union in 1991 then gave China a model of how not to liberalise politics or society.

Different systems of governance clearly have different outcomes. The stark contrast between North and South Korea (Cong 2016), or East and West Germany before 1989, show wide divergences between different models of governance in broadly similar societies. In Why Nations Fail: The Origins of Power, Prosperity, and Poverty (2012) Daron Acemoglu and James Robinson provide a compelling argument for the decisive influence of different institutional arrangements, based on a comparative study of nations.

My argument is that all institutions are experiments run for different purposes, some corrupt, some misguided, some honourable, and most a mixture of motives. Every institution embodies collective knowledge of how to achieve a mixture of objectives, such as a sense of belonging, security, goods and services, employment, and personal ambitions. Treating institutions as proto-scientific models offers social science a productive approach to solving problems and achieving better outcomes in society.

People have conducted social experiments in solving collective problems for millennia, testing and developing different forms of civilization, * democracy (Keane 2009), cities, * nation 
states $*$ and enterprises. The global coronavirus pandemic has shown significant differences in the ability of states to contain the pandemic (Greer et al 2020; Johns Hopkins Coronavirus

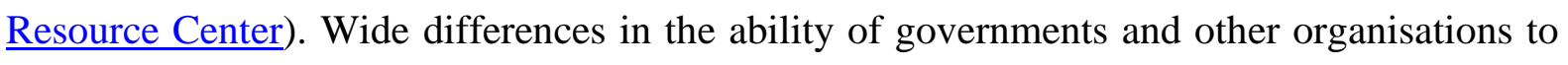
achieve their objectives provide a fertile source of evidence about what works. Societies differ greatly in their ability to conduct and learn from natural experiments, which is where political science and civic education have a crucial role. Scholars can improve public understanding and decision-making through more detailed analysis of case studies and comparisons. Mariana Mazzucato's Mission Economy (2021) analyses the successful social experiment by President Kennedy's government to put men on the moon, drawing out lessons for how modern governments can tackle big, ambitious goals. Fine-grained comparisons and case studies "can be highly useful instruments in scientific political inquiry." (Lijphart 1971: 693). But the ultimate test of any social inquiry is its ability to help people improve social conditions.

\subsection{Reflexivity, social learning and research}

Second, societies and their institutions are by their nature reflexive. That is, people respond and adapt to their environment, changing their behaviour and institutions in response to events, information and ideas. Sociologist Anthony Giddens observed that "Modern societies, together with the organisations that compose and straddle them, are like learning machines, imbibing information in order to regularize their mastery of themselves." He concluded, "Only societies reflexively capable of modifying their institutions in the face of accelerated social change will be able to confront that future with confidence." (Giddens 1987: 21). However, as responses to Covid19 have shown, decision-makers' willingness to modify their behaviour, policies or institutions in response to evidence varies widely. Politicians may be guided less by evidence, science or even the interests of their constituents than by self-deception (Tuchman 1984), lobbyists *, their own experience, culture and immediate environment (Bevir 2010; Gibbons 2006; Finlayson 2004;). In particular, we observe that politicians and practitioners are influenced more by their own experience and working examples than by research papers. When a new way of doing things is seen to succeed - such as the Head Start early intervention 
programme in the United States *, schooling in Finland,* 'zero-tolerance' policing in New York,* or the public health approach to reducing violence in Glasgow * - policy makers are more likely to adopt the model to improve practice. The evidence is tangible, it takes account of the complexities of real life, and is supported by positive pictures and stories. This ability of working models to influence decision-making offers a clue to making social science more reliable and credible with decision-makers.

\subsection{Institutions as the equivalent of theories in the physical sciences}

This leads to the third and most difficult part of this argument, which is that an institution can be seen as the equivalent of a hypothesis or theory in the physical sciences. Theories - models of reality - give humanity enormous ability to harness the power of nature. Scientific models enabled the European Space Agency's Rosetta mission to send instruments 24 million kilometres into space and land on a comet four kilometres wide flying at 135,000 kilometres per hour. Models of subatomic forces enable companies to mass-produce miniature circuit boards that manipulate atoms in a smartphone so that people can connect worldwide and access vast stores of knowledge through the internet. Social sciences have no equivalent method of modelling social reality to unlock the potential of human societies. Indeed, the very concept of theory in social and political sciences is contested (Turner, J H. 2012, 2014; Grant 2002; *).

I suggest institutions can be seen as working models that embody collective understanding about how to achieve certain outcomes in society. A synagogue, school or street market is recognisable across centuries, countries and cultures. Each institution embodies knowledge of how to deal with their bit of social reality and achieve their purposes over time, while adapting and negotiating their place in shifting power relations and external conditions. Institutional models are scaled up, refined, and replicated to provide similar functions in many different societies. Every institution is an experiment, in which people test and adapt its practices to achieve their aims in a particular environment. 
People's beliefs are an intrinsic part of any institution, together with the routines, rituals and relationships that keep it going. Ideas and emotions are powerful drivers for people who create, run, challenge or change institutions, but people's beliefs about what they do and why are less important than the institutional processes they use to make things happen. Institutional behaviours and structures are more persistent than the beliefs which guide them, as can be seen, for example, in the continuities of form and function from ancient temples to synagogues, churches, mosques or even secular social movements and network marketing. * Institutions are more tenacious than changes in ideology, as shown by millennia of Chinese civilization * or the persistence of imperial state structures in Russia after the revolutions of 1917 and 1991 *. People adopt and adapt institutional structures and patterns of behaviour to achieve equivalent outcomes in different contexts, even if their language and ideas change. ${ }^{*}$ Ideas, theories and evidence from social research can influence institutions, sometimes at scale, so they are important parts of many social models.

Treating institutions as equivalent to theories in the natural sciences can be understood in terms of generic models, like business models or different models of government, but I suggest it is more productive to see every institution as an ongoing experiment and social model of how to deal with an aspect of social reality. Generic analyses of different models are useful, but people constantly refine their institutions so that actual institutions are the most up-to-date version of any particular model. My working paper on Institutions as Social Theory explores this in more depth (Alexander 2021). There is also a philosophical argument that all knowledge of society is a social construct and reflexive by nature, so that its representation in behaviour and social institutions is more objective than concepts or language.

\section{A THEORETICAL ASIDE}

\section{Karl Popper and theory-incorporating organic structures}

The idea that institutions embody theories recalls Karl Popper's observation that "organic structures are theory-incorporating as well as problem-solving structures." He wrote "practical 
problems arise because something has gone wrong, because of some unexpected event. But this means that the organism, whether man or amoeba, has previously adjusted itself (perhaps ineptly) to its environment, by evolving some expectation, or some other structure (say, an organ). Yet such an adjustment is the preconscious form of developing a theory; and since any practical problem arises relative to some adjustment of this kind, practical problems are, essentially, imbued with theories." (Popper 1976: 133) Organisations are also reflexive natural experiments, learning in response to problems (and opportunities), imbued with pre-conscious theories about how to solve problems. They are also purposeful, striving to survive, amultiply and flourish in whatever environment they find themselves. *

However, many institutions are poor theories when it comes to meeting their stated objectives, and seek to meet the unstated aims of their core group instead, as described by Art Kleiner (2003). Even dysfunctional institutions continue so long as they are sufficiently adapted to their environment to survive. Changing an institution to improve its ability to meet certain social outcomes is rarely the result of a new conceptual model, new procedures or personnel, but a response to crisis or the interaction of many factors.* Successful change can quickly become a model for others, who apply the lessons to their own institutions, while vested interests can prevent ineffective institutions from changing or even promote defective solutions to benefit themselves at the expense of the majority (for examples, see Michaels 2008; Oreskes and Conway 2010; *).

\subsection{The democratic method}

This leads to my fourth point, which is that citizens have a critical role in shaping institutions to meet social objectives. Over centuries, citizens have developed civil liberties, economic freedoms, impartial rule of law, representative democracy, regulatory bodies, principles of good governance, and countless measures to make institutions meet their needs better. Democratic systems include many methods to scrutinize and develop institutions as social models. These methods have a crucial role in our natural experiments in how to meet people's 
needs. All governments are 'working hypotheses' subject to scrutiny by official procedures, political parties, elected assemblies, mass media, regulators, law courts, professional associations and other facets of liberal democracies. John Keane describes this as monitory democracy (2009: ix-Xxxiii). In this light, democratic processes can be seen as a rudimentary method of social science, through which citizens peer review their governments and other institutions.

For decades people throughout the world aspired to adopt and adapt democratic methods to govern and improve their societies. * But the spread of democracy has stumbled *. In many representative democracies, citizens have much less influence than the wealthy minorities who fund candidates, parties, think tanks, pressure groups, media and research to support their interests and mislead the public. * Defective voting systems give power to political leaders who neither represent the majority nor respect the pluralism, debate and compromise on which democratic politics depends.* Powerful minority interests also prevent citizens from creating an equitable, accountable, rule-based system of global governance in which different regimes can maintain peaceful cooperation to solve critical global issues. * As a result, supposedly democratic societies are slow at improving institutions in the common interest and losing public support. * At the same time, China shows that an authoritarian model can accelerate economic development more rapidly than liberal democracies and increase citizen satisfaction with their government (Cunningham, Saich, and Turiel 2020; Mahbubani 2020: 154). The democratic method of social improvement is in danger of being eclipsed by an authoritarian one.

In my view the undermining of democratic methods by powerful minority interests is a greater threat to human development than any existing authoritarian regime because they prevent democratic systems from being effective and create opportunities for authoritarian leaders to flourish.

\subsection{Summary of the theoretical argument}


To sum up, I propose that the reflexive nature of society provides a theoretical basis for recognizing institutions as natural experiments and "social theories" or models of how to deal with different aspects of society. Every institution includes conscious and unconscious assumptions, beliefs and philosophies that seek to explain, guide or change it according to the understanding of people involved. Democratic processes are methods to improve the ability of institutions to meet people's needs, but they are often distorted by powerful interests and can be replaced by authoritarian methods. Part 2 explores some of the implications for teaching civic engagement and Part 3 outlines seven types of higher education model for improving education and support for civic engagement.

If it helps to have a word for an institution as a social theory, I suggest simply Social Model, with capital letters to distinguish it from a generic model as a method or institutional practice, such as a business model or model of government. Alternatively, the Greek word thesmós $\left(\Theta \varepsilon \sigma \mu o_{\varsigma}\right)$ could tell it apart from theoría, a theory or system of ideas to explain something. Thesmós means institution, custom or practice, and unwritten law, as well as good counsel, which is particularly relevant in this challenging moment. For simplicity, and in line with common usage, I will use the term Social Model when referring to an institution as a collective hypothesis that embodies knowledge and practices about how to do something in society.

\section{Part 2}

\section{Directions: political science and education for civic engagement}

Treating institutions as natural experiments and Social Models subject to review by citizens has major implications for social research and the role of universities in democratic societies. In this part I want to explore four implications. First, it means that improving the ability of institutions to bring about social outcomes by creating Models of best practice could become a major focus of social research. Second, the task of identifying, studying, improving, and sharing Models of good practice should have a central role in the development and dissemination of knowledge in the social sciences, in this case examples of effective provision 
and support for civic education and engagement in democratic politics. Third, reflexivity and the democratic method mean that social research and education for civic engagement need to be a two-way street between scholars and the public. And fourth, it means developing provision on the scale needed to address democratic deficits, as identified by Pippa Norris and others, so that citizens can create a better society for all. Proving that democratic methods for governing societies than authoritarian ones would be a major research programme, just as proving that it is possible to put people on the moon or develop vaccines to contain a global pandemic. The following sections explore each of these points in turn.

\subsection{Creating Models of best practice}

The main implication of treating institutions as proto-scientific experiments and hypotheses is that social research would aim to improve the ability of institutions to achieve beneficial outcomes for society, thus creating Models of best practice ('smart' or 'next practice' as it has been called). This means questions about the purpose and governance of institutions are integral to social research, requiring the involvement of stakeholders and consent of citizens. It also means that social science will create more tangible benefits for people and is likely to receive more investment and public support, just as the physical sciences have done over the past century.

This means systematically identifying, developing, disseminating and applying appropriate knowledge of "what works" at each level. Although there are justifiable critiques of how "what works" has been used ${ }^{1}$, the method matters. Reflective practitioners and policy makers can learn from centres ${ }^{2}$ and scholars ${ }^{3}$ as well as reflective practices such as After Action

\footnotetext{
${ }^{1}$ Gert Biesta, (2007) Why “What Works" Won't Work: Evidence-based Practice And The Democratic Deficit In Educational Research, Educational Theory, Volume 57, Issue1, February 2007, Pages 1-22

2 eg Evidence Based Education, Centre for Effective Global Action (CEGA) at the University of California, Berkeley; Abdul Latif Jameel Poverty Action Lab (J-PAL) at MIT; NICE, the UK National Institute for Health Care and Excellence; New Philanthropy Capital (NPC), a think tank and consultancy for the social sector;

${ }^{3}$ Stuart Bretschneider, Frederick J. Marc-Aurele Jr., Jiannan Wu, "Best Practices" Research: A Methodological Guide for the Perplexed, Journal of Public Administration Research and Theory 15(2) December 2004 DOI:10.1093/jopart/mui017 Bardach, Eugene. 2000. A Practical Guide for Policy Analysis. The Eightfold Path to More Effective Problem Solving. New York: Chatham House Publishers.
} 
Review, course evaluation, post-legislative scrutiny etc., to improve their everyday experiments. This should be seen in terms of Aristotle's concept of practical knowledge (phronesis), John Dewey’s practical epistemologies, Vygotsky's work on meaning making, and above all the living reality of institutions that shape people's lives.

It also means scrutinising each element of institutions of academic inquiry to improve their ability to contribute to human understanding and wellbeing. In The Production of Knowledge: The Challenge of Social Science Research, William Starbuck observed that "Hundreds of thousands of talented researchers are producing little of lasting value" because they are focused on producing journal articles rather than knowledge (2006: 5, 142). Starbuck advocated that "researchers should both challenge their own thinking by disrupting their preconceptions and try to demonstrate the validity of their knowledge by observing natural experiments" (142). Some ten years later, in The Impact of The Social Sciences: How academics and their research make a difference, (2014) Simon Bastow, Patrick Dunleavy and Jane Tinkler asked "why social science research and insights have been scantily adopted in business, and have been less influential than one might expect in government and civil society; and why the public prestige and government funding of the social sciences lags so far behind that of the "physical' sciences" (Preface). They provide a detailed picture of impact, showing that "the social sciences are more exposed to competition from the full range of intermediaries" (italics in original) [ shown in Figure 1.13 than are their STEM counterparts, BELOW] such as "management consultants, think tanks, specialist consultants, survey companies, professions and media companies." (25). Social science research in the UK is more likely to be confined within the academic realm than STEM subjects. They go on to provide a detailed analysis of the demand and use of social science research by sector, with a useful discussion of the mediation of social science research.

Arnošt Veselý, 2011 Theory and Methodology of Best Practice Research: A Critical Review of the Current State, Central European Journal of Public Policy, Vol. 5 - № 2 - December 2011 - pp 98-117 
Following my approach, this analysis would inform the work by social research communities to improve the institutions of communication to increase impact. More ambitiously, research into the role of professional associations, funding regimes, university departments, research methods and programmes, conferences, peer review, publications, lectures, seminars, examinations, credentials, recruitment of learners and barriers to entry to improve the institutions of social inquiry.

Research is incomplete if it does not inform practice, so funding to develop and spread practice should be a substantial part of research programmes. However, this illustration from the UK health service (Collins 2018) reflects a common complaint across many disciplines. As Collins says, "Adoption of most service innovation needs to be seen as part of service improvement rather than the process of 'rolling out' a 'proven' approach", an
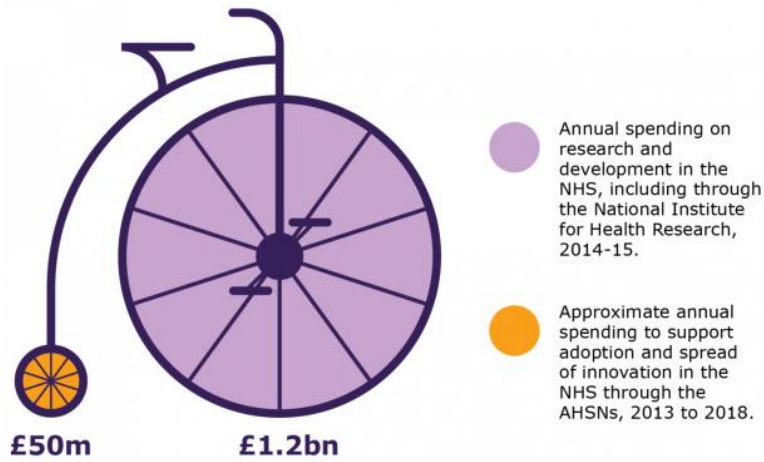
important lesson for any Social Model. From my experience the ratios should be reversed, so that research steers much greater investment in improving practice and provision.

Social researchers can produce more valuable knowledge by shifting their focus from publications within the academic realm to increasing the ability of citizens and intermediaries to improve institutions as Social Models. More rigorous methods of inquiry will enable people to develop institutions that are increasingly better at unlocking human potential to bring about outcomes they want, just as theories in the physical sciences enable people to unlock the power of nature to meet their needs.

The diversity of human societies means that different cultures, communities and groups will develop different models and methods to meet their needs. Societies and institutions will inevitably compete to prove they can do better than others, but social research will improve their ability to learn from each other and increase cooperation. Social models will change as people's purposes change. As humanity develops increasingly robust Models of global 
governance to manage the immense flows of information, finance, trade, people and disease, we can also create better Models for people to coexist, connect and cooperate at all levels. By focusing research on improving institutions as Social Models, social scientists could help bring about advances in education, health, and every area of society, including civic engagement and democratic governance.

\subsection{Institutional support for teaching civic engagement}

Civic education equips citizens to scrutinise and influence institutions of government to meet their needs better. Well-designed civic education has meaningful, lasting effects on civic engagement (e.g. Campbell 2019; Torney-Purta et al 2015). However, civic education has a low priority in most liberal democracies and relatively few citizens take part. *

Following my definition of institutions, every course is a hypothesis or Social Model about how to teach a subject that can be replicated and refined to produce better outcomes in changing conditions. Some course Models have high status and are widely replicated, such as the MBA (founded 1908 in Harvard), PPE (Philosophy, Politics and Economics), first taught at Oxford in the 1920s, or Business Studies, now the most popular subject in universities throughout the world, with over $12 \%$ of new students in UK in 2019 and $20 \%$ in US (UCAS for UK; for US see Digest Of Educational Statistics data here; see graphic for US trend, below; Williams, 2010). * Civic education should be more important than business studies, since every citizen has a say in democratic governance, while only a minority run a business. Governments allocate 20 $50 \%$ of national income (GDP) and make the rules for how the rest can be used. Most funding for education and research in science over the past century followed political decisions by governments, enabling the technologic innovations we take for granted.

* Political decisions funded the research that showed the dangers of global heating and developed technologies to deal with it. Governments make rules for businesses, which is why businesspeople are actively engaged in politics. But citizens form governments and, in 


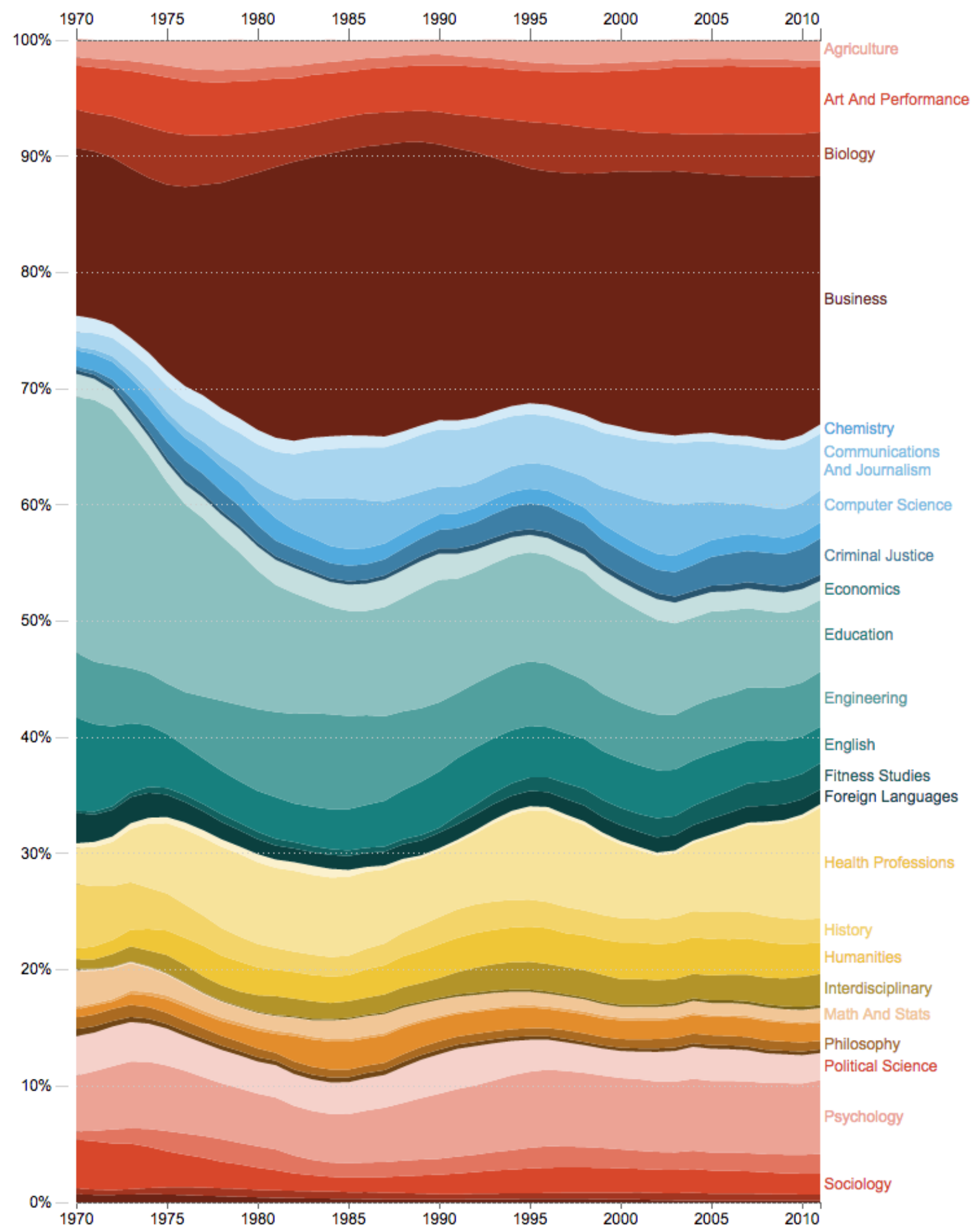

Source https://en.wikipedia.org/wiki/Higher education in the United States\#/media/File:College degrees graph.png 9 May 2014

principle, decide rules and priorities for all areas of life. Equipping citizens with confidence, knowledge, skills, and values for democracy is clearly essential for good governance.

The challenge for educators is to establish Models of provision and institutional support on a scale sufficient to the task. This is not an argument for replicating one Model of civic education like branches of McDonalds, since different participants, places, political contexts and 
purposes need different kinds of provision. The argument of this paper is that developing Social Models in practice is central for social and political science because Models embody knowledge that is replicated, and adapted to changing circumstances. It is also important because institutions have more influence than research evidence. Existing provision is largely based on the institutional priorities of education providers and funders, * rather than evidence of need or efficacy. Evaluation and research can influence priorities, but the drivers come from policymakers in universities, governments and foundations. *

To increase effective provision, therefore, scholars need to identify and develop institutional Models to improve provision for civic education, including:

- Learning providers, including universities, community colleges, adult education centres, schools, public service media and online education

- Civil society associations, foundations and governments that fund and promote provision, as well as legal, financial and policy frameworks that underpin it.

- Communities of practice, professional networks, training programmes and guides, such as Guidebook: Six Proven Practices for Effective Civic Learning (Guilfoile et al 2016), which inform and support people running programmes

Part 3 outlines seven types of institutional Model that have a key role in civic education, as a focus for research and development to create more effective education for democracy.

\section{3 Civic education as a two-way street}

A third implication of reflexivity is that developing Social Models needs to involve practitioners and other stakeholders, including citizens. Most disciplines engaged in developing institutions, such business studies, management, and operational research, mainly focus on the role of leaders and professionals in improving their Models. Civic education, on the other hand, 
aims to enable all citizens to use and improve democracy as a method, so they need to be included as equal partners.

The challenge for scholars is that many people feel the political system neither represents their interests nor responds to their needs. * In what Lora Cohen-Vogel (2019) has called the paradox of political engagement, many young people opt out of voting and opt into protest because they do not believe conventional politics can achieve their aims. By contrast, a higher proportion of older voters supported the anti-establishment campaigns for Brexit and Trump in $2016 *$ and authoritarian solutions to political problems. * The wide differences in perspective between university educated minorities and sections of the public who feel left behind in a world largely run by educated professionals is a major issue for civic educators and higher education as a whole.

In democratic societies the entire enterprise of academic freedom and scientific research depends on public acceptance and support. Citizens have a say over the purpose, conduct and funding of research through their elected representatives. The most visible effects of this are in the use of animals or embryos in research, but all research is ultimately subject to a social license and democratic consent. The rejection of evidence on critical issues such as climate, Covid19, vaccination and smoking by sections of the population and influential interest groups highlights the importance of engaging with the public to secure understanding and consent for research to flourish and its findings to be valued. For these reasons it is important to show how political science and civic education can help people change the system so that it serves them better.

\subsection{Addressing democratic deficits at scale}

This leads to a fourth implication, which is that, for the democratic method to be effective, education for civic engagement needs to be at scale sufficient for citizens to solve social problems by democratic means. The poor state of democracy in most countries, and the many problems they are failing to resolve, makes this the biggest challenge of all. 
Civic education alone cannot solve social problems, but it can equip citizens with understanding and methods to develop better Models of democratic governance to deliver better outcomes. Creating provision on the scale needed to make a significant difference requires more ambitious programmes. Large scale teamwork is common in most natural sciences to tackle complex problems like climate change, particle physics and space research. It is urgently needed to develop effective civic education at scale.

Pippa Norris's general model of democratic deficits (2011) and five dimensions of system support (1999a) provides a robust framework for developing support for citizens to improve their Models of democratic governance. According to Norris, "the democratic deficit can be explained by the interaction of rising expectations, negative news, and failing performance" (2011:5). Norris presents a general model of democratic deficits (Fig. 1) and concludes 'the democratic deficit has important consequences - including for political activism, for allegiant forms of political behaviour and the rule of law, and ultimately for processes of democratization' (italics in original).

Fig. 1 Norris's general model of democratic deficits

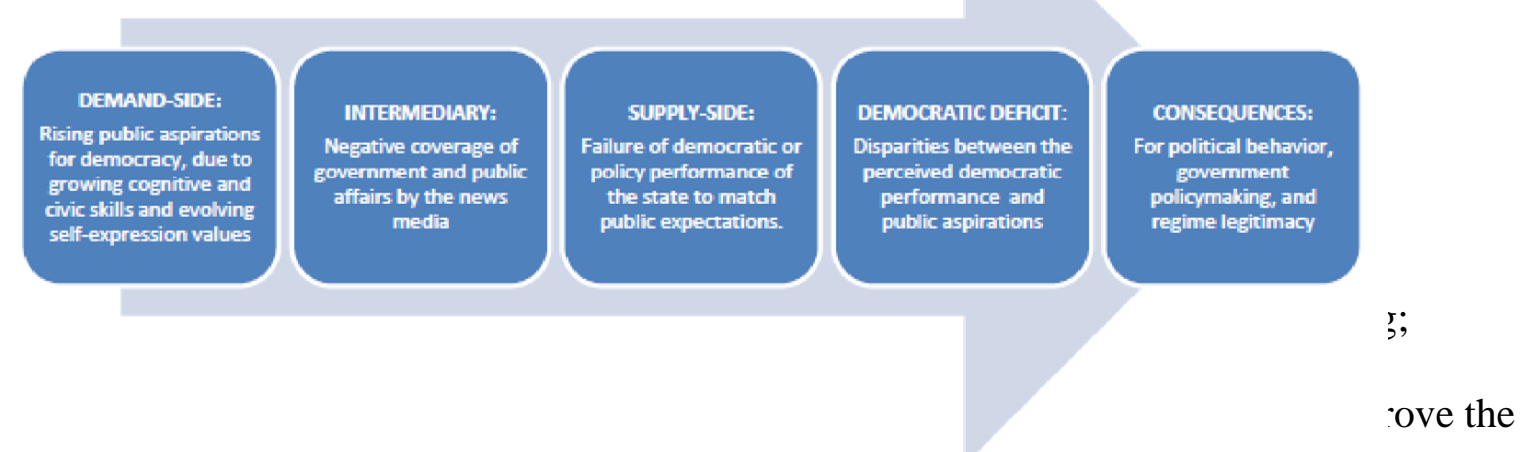

policy performance of democratic governments and their institutions. 
Norris observes in her conclusion "Overall it appears that closing the democratic deficit is therefore largely about strengthening processes of democracy and the actual quality of governance so the performance meets rising citizen expectations" (2011:245). The following sections address each of Norris's three areas in turn, to suggest how better Social Models can strengthen democratic process and the quality of governance through civic education and engagement.

\subsection{Demand side: Supporting citizens' engagement in democratic governance}

Norris summarises many of the factors that contribute to "public aspirations toward democratic ideals, values, and principles, or the demand for democracy" (236). In particular, "educational levels, self-expression values, social trust, and associational activism all help to predict higher democratic aspirations. Only the effects of education, however, actually widen the democratic deficit" (243). This highlights the importance of 'enlightened democratic knowledge' (143, $152,163,244)$. This knowledge "was significantly strengthened at a macro-level by longer historical experiences of democratic governance" and at the micro-level, by "cognitive skills and knowledge derived from education as well as access to news media information" (244). However, the polarisation of opinion in America and many other democratic societies * shows that 'enlightened democratic knowledge' does not reach large sections of the population.

Developing Models of civic and political education with people most dissatisfied, disenfranchised or disillusioned with the current system is therefore a major challenge. Civic education can learn from other disciplines such as health promotion, ${ }^{*}$ agricultural extension,* participatory action research (Berold 2012; Chambers 1983, 1997; Reason 2008), system-based participatory action research $(*)$, Asset Based Community Development $(*)$, community organising $(*)$, and the pedagogy of Paulo Freire $(*)$, among others. These approaches start from where people are and work with local communities to bring about change from the outside in, rather than the top-down approaches of most Models of organisational change. These methods of learning and research are also informed by a profound democratic commitment to 
enabling all citizens to have an effective voice in society. Civic engagement can also learn from marketing and behavioural sciences. *

However, none of these are sufficient to provide civic education at scale. They need to be accompanied by activities to foster social trust, associational activism and reliable news media. Here we can learn from Scandinavian Folk High Schools and study circles, which had a formative role in their national identities as social democratic nation states (Nordvall 2009). They provided Models that have been widely adapted in other countries on a smaller scale, such as Highlander (Toiviainen 1995) and Everyday Democracy.

\subsection{Intermediate factors: the social ecology of knowledge}

Intermediate factors can be addressed by engaging with political communication and social learning, to develop critical thinking skills, challenge falsehood and provide accessible, accurate and authoritative evidence on problems, what I have called "intelligence services for democracy" (Alexander 2016: *). A related area for action, therefore, is the social ecology of knowledge of political science, so that citizens, policymakers, and practitioners can use research effectively. Bastow et al. describe (2014) how findings in social sciences percolate into use through news media, books, consultants, management training, think tanks, pressure groups and popular culture, as well as academic services to business and government. "Much of the world's work of problem solving is accomplished not through PSI [Professional Social Inquiry] but through ordinary knowledge, through social learning, and through interactive problem solving." (Lindblom and Cohen, 1979: 91). This means understanding, developing and using the array of methods to communicate and work with the users, staff and governors of institutions, involving citizens in

- Setting the agenda and topics for research

- Involving potential users in the design, development and dissemination of findings

- Monitoring and evaluating outcomes to create cycles of continuous learning and development. 
The key point is that academia is part of an extensive ecology of institutions that fund, create and use knowledge in a world where most people rely on personal networks, social media and mass media. * The most influential players, such as leaders in big business, finance and government, get and use institutional power under the rules of their society on the basis of charm, inducements, lies, myths, threats or other methods, whether elections in democratic states, or guanxi, favours and the warped meritocracy of the Chinese Communist Party. Support for local discussion groups, study circles, adult education and news platforms can play a vital role in sharing reliable information and developing pluralistic civic cultures.

\subsection{Supply side: Improving the effectiveness of institutions as Social Models}

Perhaps the biggest challenges are supply side factors, to address constitutional inequalities of power and improve the performance of democratic governments. The rest of this part explores this challenge in more depth. Part 3 outlines several Social Models in higher education that support citizens addressing democratic deficits.

Treating institutions as natural experiments and "theories" in social sciences creates opportunities for research to increase social innovation and improvement. This includes the unglamorous but essential task of improving existing practices, as well as creating disruptive institutional models and improving the democratic method in practice.

A key area is to improve the methods used by institutions to monitor and develop their work by collaborating with practitioners and policymakers on

- Systems for collecting, analysing and using data to improve performance: modern institutions collect and analyse vast amounts of data about finance, services and users to meet requirements of funders, regulators, marketing or public relations. Data is usually collected for narrow institutional purposes and compliance with external rules rather than systematic research to improve outcomes for society. Governments also use data and funding formulae to allocate resources for different purposes, without systematically using the flow of information to improve institutional performance and 
social outcomes. Work with practitioners and decision-makers could improve the use of data to enable organisations to achieve better social outcomes. This is not as easy as it sounds. A McKinsey study of more than 100 higher-education engagements across North America over five years identified numerous obstacles to using performance data effectively, including focus on external compliance, reluctance to share data, poor data hygiene, lack of appropriate skills, budgets, and other constraints. The lead time to get buy-in and install better systems can take two to three years before seeing tangible outcomes from using data better (Krawitz et al 2018). ${ }^{4}$

** and Institutions' Use Of Data And Analytics For Student Success by Amelia Parnell, Darlena Jones, Alexis Wesaw, and D. Christopher Brooks (2018), National Association of Student Personnel Administrators, Association for Institutional Research and EDUCAUSE. For another example from a completely different field, see $\underline{\text { Challenges }}$ and Opportunities for Collecting and Sharing Data on Water Governance Institutions, Samuel Gallaher \& Tanya Heikkila, 22 July 2014 https://doi.org/10.1111/j.1936704X.2014.03181.X The main point of these studies is not academic analysis, but rigorous understanding to inform practice, i..e. the performance of institutions as working models.

- Objectivity in decision-making: institutions use systematic forms of detachment to improve decision-making, such as external advisers, boards, consultants, auditors, ethics committees, feasibility studies and other measures. Societies also create many different forms of external scrutiny to improve the performance of institutions, such as complaints mechanisms, courts, judges, juries, journalists, inspectors, regulators,

\footnotetext{
${ }^{4}$ Mark Krawitz, Jonathan Law, and Sacha Litman (2018) How higher-education institutions can transform themselves using advanced analytics McKinsey, see also:

Amelia Parnell, Darlena Jones, Alexis Wesaw, and D. Christopher Brooks (2018) Institutions' Use Of Data And Analytics For Student Success, National Association of Student Personnel Administrators, Association for Institutional Research and EDUCAUSE. Samuel Gallaher \& Tanya Heikkila, (2014) Challenges and Opportunities for Collecting and Sharing Data on Water Governance Institutions, https://doi.org/10.1111/j.1936-704X.2014.03181.X
} 
indices, due-diligence and many more, all of which can be improved through social research methods.

- Comparative studies to identify and analyse different institutional models and practices, such as the work of Pippa Norris, * Arend Lijphart, Hall and Soskice on Varieties of Capitalism (2001), Acemoglu and Robinson on Why Nations Fail (2012) and The Narrow Corridor (2019), or Kathleen Thelen's Varieties of Liberalization and the New Politics of Social Solidarity (2014).

- Testing of alternative models to deal with specific social issues, from community safety and health promotion to democratic systems and global governance. *

These activities are in the tradition of reformers who set up the London School of Economics, Chicago School of Economics and numerous policy centres, but current incentives to publish peer reviewed papers means there are fewer resources for the more demanding, less glamorous and unpredictable work of assisting citizens, practitioners and politicians to develop better institutions. Peer reviewed papers have a place in evaluating the development and impact of work on Social Models and natural experiments, as part of the deeper social learning process, but the proof of social research is demonstrated through social outcomes sustained over time, not citations. Part 3 considers a range of institutional Models in higher education that support civic engagement that could assist humanity's experiment to create effective democratic governance.

\section{Part 3}

\section{Collaborations: universities as agencies for democracy}

This part aims to show how higher education can help people to improve democratic governance as part of humanity's ongoing experiment in how to run societies. So far this century, China has shown that its authoritarian Model of governance is often better at improving social conditions and satisfying the majority of citizens than many democracies, 
particularly in developing countries where most people live (Morrison 2019, Szunomár 2020, World Bank 2018). Democratic societies need to prove that their experiments in government are better at serving citizens and solving problems or they could be side-lined by authoritarian Models, or even supplanted, as they were in Italy in 1922 and Weimar Germany in 1933. The storming of the US Capitol in January 2021 by supporters of President Trump, crackdown on pro-democracy activists in Hong Hong, and suppression of opposition in Belarus, Myanmar, Russia, Thailand, Turkey and elsewhere highlight the vulnerability of democratic governance. *

There are good reasons to be sceptical about universities' potential to support learning for democracy. They provide research, education and intellectual justification for leaders and professionals in every kind of regime, both authoritarian and democratic. * Academic career structures incentivise scholars to publish papers on clearly defined, discrete topics rather than engage with citizens in the messy complexity of social reality. * Many universities are run as businesses, selling exclusive access to knowledge, professional careers and privileged occupations, with token support for civic engagement.* Most important of all, one of the biggest social divisions today is between university educated professionals, who tend to have more secure, better paid jobs with a pension, and the majority without higher qualifications, who work in hospitality, retail, distribution, manufacturing, or precarious manual occupations on lower incomes. * Universities' contribution to democratic engagement is highly questionable, given that after more than a century of professional political science, one hundred years after John Dewey's Education and Democracy, and 35 years of the Campus Compact, democratic governance in the United States remains vulnerable. Civil society, independent state agencies or other institutions may be better at supporting civic engagement and democracy than universities, so their role in strengthening democracy has yet to be tested.

Seven reasons why universities could strengthen democracy 
However, the idea that universities could have a significant role in strengthening democratic governance and civic engagement is a hypothesis worth testing for at least seven reasons: -

1. Universities are among humanity's most respected and widespread institutions for learning, teaching, research and professional practice.

2. They educate future leaders and higher-level practitioners in most areas of society.

3. They have more secure funding, better premises, more extensive networks, and greater influence with business and governments than civil society associations or other agencies that support civic engagement.

4. In many liberal democracies more than half of all school leavers attend universities.

5. A growing number of universities and academic departments are developing their civic role and work with local communities as well as policymakers and the media.

6. Scholars can bring respect for evidence, critical thinking and a wide range of research methods to bear on institutional Models.

7. Academic freedom gives faculty and students scope to set their own agenda, subject to funding as well as institutional priorities, so that they have the freedom, authority and access to resources to lead major initiatives at scale.

The international response to the coronavirus pandemic has shown how scientists can advise governments, inform the public, and develop prophylactics at scale. Scholars collaborated internationally with private and public sector agencies to gather evidence, develop and test vaccines. They also lobbied governments to fund and implement measures they considered necessary to protect the public. Political scientists could do the same to strengthen democracy.

I may be wrong. Universities could maintain their role as gateways to privilege under market fundamentalism, state authoritarianism, anti-democratic populism or whatever regime becomes the dominant model of government in future. But they have a choice. 
The rest of part 3 outlines existing Models of university support for democratic engagement at seven levels of organisation, starting with micro institutions (1), course programmes and curricula (2), then issue-based partnerships (3), university-wide models (4), brokerage models (5), collaborative networks, including professional associations (6), and system-wide models (7). In some cases I will contrast Models from liberal democracies with those from China to highlight issues. This is not a comprehensive list nor scholarly analysis but outlines a possible programme of research and development in support for more effective and inclusive democracies. Ideally such a programme would be developed at scale, by leaders of higher education in partnership with civil society, public services, and funding bodies to improve system-wide provision through collaborative networks and all seven levels outlined below. Scholarly analysis and small-scale programmes have so far failed to strengthen democracy, but in reality the drive for democracy may have to come from teacher-scholars determined to improve civic education and engagement from the small-scale outwards, so this is where I will start.

\section{1) Micro-Models: Procedures, rituals and symbolic acts}

Many small, repeated social practices have a significant influence on people's sense of agency, belonging and other aspects of citizenship. A flag in the classroom, the Pledge of Allegiance, how new students are inducted into an institution or class, prize giving and graduation ceremonies, and countless routines shape the work and impact of a learning community. Symbolic actions, such as 'taking the knee' for Black Lives Matter, Greta Thunberg's School Strike for Climate, the \#MeToo hashtag, wearing a hijab, cross or Make America Great Again cap are significant acts that become micro-institutions by being replicated to affirm or challenge particular beliefs, norms, and values. In China, Confucius's teaching on the importance of ritual, ceremonies and everyday etiquette (known as $l \grave{l}$, 禮, proper rite or custom) is still a fundamental pillar of social and political order over two thousand years after his death in 479 BCE.* The Hippocratic oath, written between the fifth and third centuries BCE, contains 
principles that continue to guide medical practice today (Jouanna 2001), and is a model for codes of conduct in other professions. The Hippocratic oath and $l \iota$ are examples of tried and tested social theories. Set-piece events like the inaugural speech, public lecture or commencement address are micro-institutions with ancient origins, used to reinforce traditions or give new meaning and direction to a larger institution or society. Entrance exams, access programmes and scholarships are some of the many micro- or mini-institutions that define higher education in practice.

How educators use rituals, symbolic acts and other recurring events says a lot about who is welcome, what is valued, expectations, norms, and how to take part. The smallest acts can convey the whole, either to ensure compliance and conformity, or to create citizens who think for themselves, question assumptions, seek reliable evidence, are open to challenge, curious about opposing views, and able to make a difference in the world.

Lessons in any subject can enhance civic engagement through micro-institutions such as electing class representatives and devils' advocates; setting up study buddies, huddles, buzz groups, peer coaching, mentoring, or action learning sets; inviting activists and practitioners to speak; basing assignments on real-life tasks; twinning with learners in the local community or other countries; learning through projects or community service; and making time for reflection and feedback at the end of every lesson, meeting or course.

Every educator can ask basic questions, such as

1. What elements of my practice (micro-institutions) encourage or discourage civic engagement, and how can I make them more effective?

2. How can the routines, rituals and symbolic acts of my department and institution enhance democratic engagement by students and the wider community?

3. How do we know what impact these activities have on democratic engagement?

4. How can I increase their impact to make our democracy work better for all? 
Changing routines and symbolic actions may be easy or challenging, depending on circumstances, but they have far reaching effects. When colleges first admitted women to study, they began to erode deeply entrenched institutional practices. * When Rosa Park defied segregation laws by refusing to give up her seat to a white passenger on a bus in Montgomery, Alabama in 1955 , she challenged a micro-institution backed by state law, contributing to the long struggle for civil liberties. * Symbolic acts and changes to micro-institutions like admissions criteria or seating are small but powerful experiments in increasing support for civic engagement.

\section{2) Courses and programmes: Models of learning in action}

Every course is a mini-institution and Social Model about how to develop civic skills, values, knowledge, experience, and a sense of efficacy in a structured way, involving both classroom and experiential learning. However, as Educating for American Democracy points out, the US spends “approximately $\$ 50$ per student per year on STEM fields and approximately $\$ 0.05$ per student per year on civics." It is unlikely that many countries spend much more, except perhaps Germany, or China, where civic education aims to uphold authoritarian rule.

For examples of Models and resources for education in civic engagement for democracy see:

1. Teaching Civic Engagement, edited by Elizabeth C. Matto from Rutgers University, offers "how to guides" on learning active citizenship, research, and interactive platforms for educators preparing students to be active participants in the democratic process, and a companion to the volumes Teaching Civic Engagement: From Student to Active Citizen and Teaching Civic Engagement across the Disciplines

2. Civic Engagement Research Group (CERG) at the University of California Riverside, which conducts research, develops resources, and advocates education reform to promote equitable, informed, and effective youth civic and political participation. 
3. Educating for American Democracy is a collaboration among over 300 academics, historians, political scientists, $\mathrm{K}-12$ educators, district and state administrators, civics providers and students to support civic learning opportunities.

4. Active Learning in Political Science is an online community of practice with a section on community and civic engagement

5. Social Action Course Initiative, run with Scott Myers-Lipton, San Jose State University, author of CHANGE: A student Guide to Social Action (2017) and A Guide to Teaching Social Action (forthcoming, 2021), a "learning and doing" community of social action teachers

6. The Bonner Program is a well-developed educational model for a four-year, servicebased college scholarship program that recruits and supports low-income, first generation students committed to changing the world through service, with a network of participating colleges, universities, nonprofits and alumni.

My book on teaching practical politics aims to provide an overview of why and how the subject can be developed to teach practical politics in different sectors (Alexander 2016).

Setting up systems to share practice, collect data and conduct multi-dimensional evaluation can inform the development of each Model, or its replacement if it does not achieve its objectives, or its objectives are misconceived. Evaluation methods are therefore a necessary part of any course programme. It is important to assess, use and choose an appropriate Models of evaluation, such as Kirkpatrick Four Levels Evaluation Model (Kirkpatrick 1993; 2016), its alternatives (Tamkin et al. 2002) or one of the 30 models discussed in Assessing Civic Competency and Engagement in Higher Education: Research Background, Frameworks, and Directions for Next-Generation Assessment (Torney-Purta et al 2015).

Key questions for educators developing civic engagement in their courses and institutions include -

- What are the needs and opportunities for civic education and engagement in my area? 
- Where can I find a community of practice, to develop my thinking and practice as well as mutual support?

- How do I create a community of learners with democratic values and practices to meet the needs of my students and community?

- What model of evaluation will enable me to continuously improve its impact?

- What institutional support do I need to make my courses accessible and useful to those who can benefit most?

Any course or programme is important for participants, and potentially life-changing, as well as a Model from which others can learn. A civic education programme can also set out to influence the university to make education for democracy a priority, but it may be easier and more effective to develop provision for civic engagement on specific issues, as in the next level.

\section{3) Issue-based Partnership Models}

The most widespread Models of support for democratic engagement are specialist centres where academics work with practitioners and other stakeholders to provide expertise, knowledge and support. Many issue-based partnerships also take part in Collaborative Networks (6) and Knowledge Brokerage (5) in their specialist area, such as the Coalition for Epidemic Preparedness Innovations (CEPI) to accelerate development of vaccines against emerging infectious diseases. Different Models of issue-based partnership focus on one or more of the following roles:

1) Pro-bono clinics, which give students real world experience by providing advice and support to the public under professional supervision, such as law clinics and innocence projects in legal education, planning advice centres, public health projects and many other areas.

2) Public information, such as the Academic Freedom Monitoring Project, run by $\underline{\text { Scholars at Risk at New York University (NYU), Harvard's Electoral Integrity }}$ 
$\underline{\text { Project, the Costs of War Project at Brown University, the much quoted Coronavirus }}$

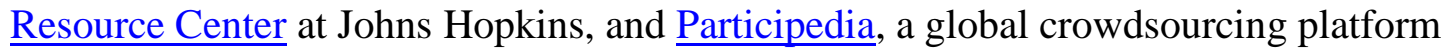
for researchers, activists, practitioners, and anyone interested in public participation and democratic innovations.

3) Resource centres, such as Tools to change our world, a Community Tool Box run by the Center for Community Health and Development at the University of Kansas, offering support for taking action, training, and sustaining change. At least 77 campuses across the US have Civic Engagement Centres.

4) Research, innovation, development and advocacy (RIDA), such as

- Work on Citizens' Assemblies and Deliberative Polling by Stanford's James Fishkin to help people resolve complex issues (Democracy when the People are Thinking)

- The Urban Institute in Washington, DC, advances well-being of people and places across the US through research into social and economic issues, translating findings for diverse audiences, applying them to real-world problems to find solutions, and sharing them in accessible ways with policymakers at every level to improves decisions that affect people's lives.

- The Abdul Latif Jameel Poverty Action Lab (J-PAL) at MIT, to reduce poverty by developing policy informed by evidence from a network of 227 professors at universities around the world.

- Arizona State University's Global Institute of Sustainability and Innovation hub of sustainability research initiatives and active contributor to over 30 local and global collaborative networks aimed at reaching hundreds of millions of people to bring about sustainability at scale. 
5) Convening, hosting and facilitation, such as the Political Literacy Oversight Group (PLOG) chaired Sheffield University's James Weinberg, which supports the UK network of citizenship education providers.

6) Policy development and advocacy, undertaken by many centres.

This is a tiny sample from thousands of specialist centres in universities across the world that enable citizens and practitioners to make more informed interventions in civic life, public policy and the political process. Key questions are similar to those for Collaborative Networks, focused on impact and influence on relevant policy areas. In particular, it is worth understanding:

1. Which of these roles have the most impact, in what contexts, and why?

2. What contribution to effectiveness are made by different activities, such as blogs, conferences, convening, outreach, press coverage, providing evidence to public inquiries, peer-reviewed publication, social media, talks, etc?

3. How best to work with citizens most affected by the relevant policy area, particularly those in marginalised and disadvantaged communities?

4. What capacity and scale of provision is needed to address particular issues?

5. What forms of collaboration between centres, citizens, media, politicians, policymakers and pressure groups are most effective?

In many policy areas it is necessary to reach tens or sometimes hundreds of millions of people to have an effective impact. Many centres may be too small to have a significant impact and would benefit from working more systematically with other centres through collaborative networks (6), so these are important research questions.

\section{4) University-wide Models}

Every university teaches a "hidden curriculum" of behavioural norms, expectations, perspectives and values that is "implicit and embedded in educational experiences in contrast 
with the formal statements about curricula and the surface features of educational interaction" (Sambell and McDowell 1998: 391-392). Some make their hidden curriculum explicit, promoting their access to elite jobs, public service, or social justice. For most universities civic engagement is more symbolic than substantial, which comes and goes according to funding opportunities, staff interests, student priorities or external pressures.

The challenge for academics, students and communities who want greater commitment to education for civic engagement is to get support from funders and decision-makers. Existing Models offer lessons and inspiration, although few provide the depth and breadth of support that would give students, let alone citizens, the ability to have an effective say in their society. Most universities provide more support for business than for democracy or social action (read Raewyn Connell on The Good University: What Universities Actually Do and Why It's Time for Radical Change (2019), and Slaughter and Leslie (1997) on 'academic capitalism'). However, many universities offer Models from which to learn. I won't attempt to describe the variety of Models but point to a few examples to illustrate their range:

- The University of the Western Cape (UWC) became a 'system defying' Model, or 'struggle university' under apartheid in South Africa, proving intellectual, moral and sometimes practical support for resistance against the state following protests by students and the appointment of a coloured rector in 1975. UWC continues to "Seek racial and gender equality and contribute to helping the historically marginalised participate fully in the life of the nation " as part of its mission. It has a research unit ( $\underline{\text { ACCED }})$ dedicated to "questions of governance and development from a citizencentred viewpoint, prioritising the role of grassroots organisations and movements in their quest for more inclusive, democratic policies." Most African universities present community-university engagement (CUE) to address socio economic problems as their 'third mission', but South Africa and UWC are among the most developed programmes (Walters \& Openjuru 2014). 
- Columbia's Cooperative University was created by members of the cooperative movement to "improve the quality of life of communities through the solidarity economy by training politically oriented professionals who think and act autonomously about societal issues that promote the greater good." It has 52,000 students at 18 campuses around the country and provides services to low-income communities through specialist clinics for agriculture, dentistry, counselling, engineering, enterprise support, health, legal, provided by groups of students guided by a professor from the relevant discipline.

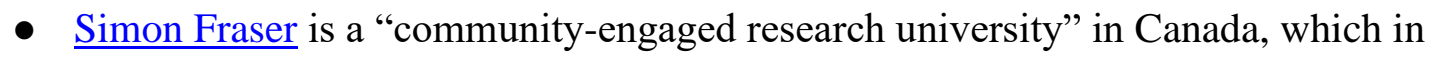
2012 adopted a strategic vision to integrate "innovative education, cutting-edge research, and far-reaching community engagement" with an international strategy to engender an active global citizenship among students, faculty and staff, and contribute internationally. (For more see http://www.sfu.ca/engage.html).

- The Propel Centre in Atlanta, USA, is a new model campus and global hub for Historically Black Colleges and Universities (HBCUs) to "drive transformative change"and educate "civic-minded leaders capable of dismantling systemic injustice, while shaping the future through innovation and entrepreneurship."

- Sussex University has put 'learning to transform' at the centre of its approach, based on four areas: learning, research with impact, engage for change, and build on strengths.

- University College London is a Corporate Model with over 41,000 students and 7,700 academic staff, which champions disruptive thinking, six cross-disciplinary Grand Challenges, 'wisdom inquiry', public policy engagement strategy, volunteering opportunities for students, and an annual two week_Global Citizenship (for which I taught campaigning). UCL aims to be transparent about its own lobbying and policy

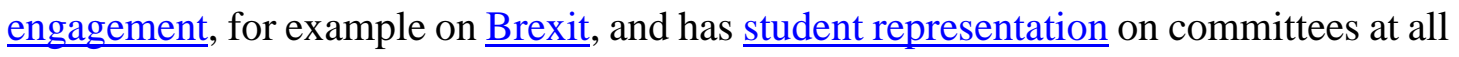


levels of the institution, shaping education policy and contributing to decision-making.

Many centres actively contribute to public policy development, like Institute for Innovation \& Public Purpose (IIPP) and a Policy Impact Unit in the Faculty of Engineering Sciences.

It takes determination, persistence and often courage to make civic engagement a priority in higher education. Existing Models can provide useful lessons and show what is possible to inform development elsewhere.

Questions for developing civic engagement and learning for democracy at an institutional level are:

1. What are the priorities for civic engagement among citizens in your area? How do you know what they are?

2. What provision currently exists, how effective is it, who are the leading champions, and can you work with them?

3. Who are the key decision-makers and influencers in your institution, and what do they need to make civic education and democracy a priority?

4. How will citizens have a voice in developing your Model and its decision-making?

5. How will you know if it is working and enabling citizens to achieve better outcomes?

6. How will you respond to criticism or attacks from powerful interests which resist democratic scrutiny?

These are mainly political questions, but the first and fifth require systematic research to inform practice, policy and decisions. The Carnegie Foundation Elective Classification in Community Engagement, run by the Public Purpose Institute at Albion College, offers an evidence-based process of self-assessment and quality improvement to recognise community engaged campuses.

\section{5) Brokerage Models}


Knowledge brokers aim to make academic knowledge and research skills accessible to practitioners, policymakers or the public. The most well-established Models are in health, applied sciences and fields with commercial potential. There are some useful analyses, case studies and reflections on knowledge brokerage in these areas (see Sources: brokerage models). Effective brokerage between citizens and higher education institutions can give people access to data, research support and policy development, creating a more level playing field between them and the industry associations, government agencies and large nonprofits.

I am not aware of studies in knowledge brokerage to support citizens' participation in public policy, so will mention just three examples from my own experience:

1. Community Partnership Model: Brighton's Community University Partnership Programme (CUPP) helps local community, voluntary, social enterprise and statutory organisations to develop ideas into projects, offering start-up funding, student volunteers, access to the university's knowledge base and communities of practice, and support for evaluation. Since 2003 CUPP has worked with over 150 academics, 3000 students and 500 community partners to address marginalisation and inequality issues, and embed social engagement into university policy, teaching and research. A video $\underline{I n}$ It Together documents CUPP's journey from inception to a portfolio of 70 projects. Learning to Make a Difference is a series of reports on the professional practice of student-community engagement and the higher education curriculum.

2. Regional Observatories bring researchers, practitioners, private sector and civil society together to gather evidence and seek solutions to policy challenges in a geographical area. In England they were set up by policymakers to improve evidence-based decisionmaking, with "Thematic Modules" covering cross-cutting policy themes and "Local Intelligence Networks" (LINs) for specific geographies. Other Regional Observatories cover larger areas, such as Economic Commission for Latin America and the Caribbean (ECLAC), the Regional Observatory on Planning for Development in Latin America 
and the Caribbean. From my experience most Observatories have little involvement of citizens and civil society organisations, but some do, and all have the potential to enhance citizens' engagement in local policy development.

3. The Dating Agency Model: the Scottish Policy and Research Exchange (SPRE) acts as independent broker between policymakers and academics, drawing on a network of 27,000 academics. SPRE takes pride in working with early career scholars and increasing the diversity in voices contributing to the evidence base for policy, representing many disciplines, professional backgrounds and methodological approaches. It also trains researchers on how to provide evidence to policymakers and offers a range of online resources. SPRE is funded by donations from universities, policy institutes and the Scottish government, with a cap of $£ 10,000$ a year from any agency to maintain autonomy.

Relationships between academia and policymakers tend to be at higher levels of decisionmaking than with local government, communities or the wider public, but brokerage between citizens and researchers can help people solve problems in their area better. The key question is, how can every university and researcher be affiliated to pro-active brokers to make knowledge usable by citizens?

\section{6) Collaborative networks}

Collaborative networks, associations, and umbrella groups of organisations with a common purpose and interests are a distinctive form of Social Model. They have an influential role in most sectors of society, working across and connecting hierarchical institutions (cf Castells 1996, 2005; Camarinha-Matos 2004, 2006, 20012; Fox 2010; Himmelman 2001). In The Square and the Tower (2017) Niall Ferguson argued that history is shaped by the interaction of hierarchies and networks. In higher education the following collaborative networks develop and support democratic civic engagement: 
- The American Campus Compact, founded in 1985 to promote the public purposes of higher education and building democracy through civic education and community development, with an extensive online resources centre and many practical initiatives, such as professional credentials in community engagement, support for Civic Action Plans and impact awards to recognize achievement.

- The Research University Civic Engagement Network (TRUCEN), hosted by the Campus Compact to share knowledge and strategies into institutions promoting engagement on campus and in their communities, with a useful Engaged Scholarship Toolkit for community-engaged scholarship (also called public scholarship or community-based research).

- The Democracy Commitment (TDC) is a non-partisan organization of 100 community colleges serving over 2.5 million students in 27 states dedicated to making democratic skills available to all students who desire a voice seat at the table of local, state, and national discourse and action. TDC runs a civic network for college faculty, staff, administrators, students, alumni, and scholars to expand civic capacity and institutionalize this work and expand programs, projects, and curricula for civic learning and democratic engagement.

- The National Campaign for Political and Civic Engagement is a consortium of more than 35 colleges and universities, based at Harvard University's Institute of Politics whose mission is to develop "civic minded and politically engaged students." It trains students to increase civic engagement in their campuses and communities.

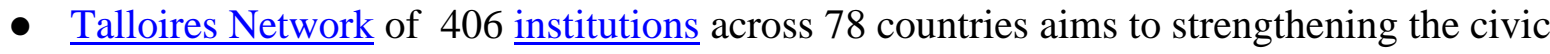
roles and social responsibilities of higher education and implement the Talloires Declaration and build a global movement of engaged universities.

- The Global Public Policy Network is a partnership of "7 prestigious universities in public policy" that aims to "address the most pressing public policy challenges of the 21 st 
century and, as a result, to have policy impact, to be influential in public policy education and training, and to be innovative in teaching and research."

The American Political Science Association (APSA) launched RAISE the Vote initiative in 2019 to "amplify and increase student engagement" in the 2020 United States elections, as well as setting up a civic engagement section with over 200 political scientists to promote teaching and scholarship in civic engagement, and APSA Educate, an online resource site with material on teaching civic engagement.

The UK has several collaborative networks for public engagement by universities, although without an explicit commitment to democracy of their American counterparts:

- The new Civic University Network of over 50 British universities, based at Sheffield Hallam University, has a resources hub to support institutions develop civic engagement.

- The Universities Policy Engagement Network (UPEN) of over 67 UK universities aims to increase the impact of research on public policy. It offers policymakers a contact point for requests for evidence; organises knowledge exchange events with government, parliament and devolved bodies; and develops best practice in policy engagement amongst universities. UPEN also promotes secondments, helps policymakers commission evidence, and organises training for civil servants and others on specific subjects, research methods or the best way to engage with academia.

- The UK's National Co-ordinating Centre for Public Engagement (NCCPE) was founded in 2008 to recognise, reward and build capacity for public engagement by universities. It publishes a wide range of resources and evaluation reports and grants and annual Engage Watermark awards to recognise higher education institutions for their strategic support for public engagement.

Many other university networks across continents, countries and subject areas support civic engagement and democratic participation by citizens. Key questions for developing collaborative networks as Social Models are: 
1. What systematic evaluation and research do they use to improve effectiveness of civic engagement and learning for democracy in member institutions?

2. Which activities or programmes are the most effective at enabling citizens to take part and solve problems in society, particularly the most disadvantaged groups, and what factors make them effective?

3. How do they engage non-member institutions and build support among people who are indifferent or hostile to democratic engagement?

4. How do they learn from each other and from collaborative Models in other sectors?

Networks also face competition from rival collaborative networks, some of which use civic engagement to challenge liberal democracy, such as:

- The Seminar Network, founded by Charles Koch in 2003, promotes social change for free enterprise through the Political Theory Project based at Brown University, grassroots organizers through the Libre Initiative, Americans for Prosperity, Youth Entrepreneurs programme and STEMIE Coalition to bring invention and entrepreneurship education to 10 million students annually across the US, and many more projects.

- $\quad$ Turning Point USA "whose mission is to identify, educate, train, and organize students to promote freedom" and "build the most organized, active, and powerful conservative grassroots activist network on high school and college campuses across the country." It has a presence on more than 2,000 US campuses, providing activism $\underline{\text { kits, }}$ grants and a 'Professor Watchlist' to expose "professors who discriminate against conservative students and advance leftist propaganda in the classroom". It launched Education Watch in the UK, which has little support.

- The Leadership Institute provides training in campaigns, fundraising, grassroots organizing, youth politics, and communications to "teach conservatives how to 
succeed in politics, government, and the media." It also runs Campus Reform to

“exposes liberal bias and abuse on the nation's college campuses."

- The United Front Work Department of the Central Committee of the Chinese

Communist Party sponsors collaborative networks in higher education worldwide to promote China's domestic stability and global outreach (Takashi Suzuki 2019).

Every national and local context is different, so no Model will work everywhere, but people who run a Social Model learn from each other and adopt practices to strengthen their cause.

\section{7) System-wide models}

Relationships between higher education, citizens and the state at a system-wide level vary widely between countries, with profound implications for teaching civic engagement at a local level. To highlight these implications I will briefly contrast China and the United States as examples of system-wide authoritarian and mixed-market Models, then draw out four key questions.

In China higher education has had a central role in educating rulers and government officials for over three millennia (Lee 2000: 41ff). Universities "played an important role in the economic construction, science progress and social development ... for the construction of socialist modernization" under Chairman Mao. Now Chinese higher education reform aims to "smooth the relationship among government, society and HEIs, setting up and perfecting a new system in which the state is responsible for the overall planning and macro management while the HEIs follow the laws and enjoy the autonomy to provide education according to needs of the society" (China Education Centre 2020). The Chinese Model includes state and private universities that produce research "according to needs of the society" and priorities set by the ruling Communist Party. These are to educate "builders and successors for the socialist cause, who are developed in an all-around way-morally, intellectually and physically" (MOE 1999 Article 4). "The task of higher education is to train people to become senior specialists imbued with the spirit of creativeness and the ability of practice, to develop science, technology and 
culture and to promote the socialist modernization drive" (Article 5). China has the second highest number of top universities after the United States according to influential university rankings. * The government encourages its most able young people to study business and technology at elite universities abroad, while at the same time maintaining close surveillance and limits on political freedoms at home. * It enjoys widespread support from the majority, whose living standards have risen substantially since China joined the World Trade Organisation in 2001, but uses repressive measures to control dissenting minorities in Hong Kong, Inner Mongolia, Tibet, and Xinjiang, where the state runs large internment and reeducation camps to curb terrorism, officially called Vocational Education and Training Centers (see Xinjiang Documentation Project, University of British Columbia). The Chinese system also promotes understanding and support for China's priorities abroad through Confucius Institutes, and actively opposes liberal democracy as a model. The relative success of the Chinese Model in academic league tables and economic growth raises profound questions for liberal democracies. These questions are explored from contrasting viewpoints in Hidden Hand: Exposing How the Chinese Communist Party is Reshaping the World (Hamilton \& Ohlberg 2020) and Has China Won? The Chinese Challenge to American Primacy (Mahburani 2020), among others. *

The American Model of higher education does not have system-wide guiding principles, apart from market forces. The United States has had a commitment to civic education since at least 1799, when George Washington left money for a university to train young people in "the principles of politics and good government" (Daniels 2020). A century later John Dewey's Laboratory School (Mayhew \& Edwards 1936) and book Democracy and Education (1916) inspired generations of teachers to develop democratic education, largely marginalised by more instrumental models of schooling.* After World War 2 the Truman Commission on Higher Education for American Democracy (1948) established a network of public community colleges. * However, since the late 1970s business has become the largest subject area and higher education has become a competitive market for students, funds, scholars and prizes 
(Nelson 2012; *). Academic associations, funding bodies, individual universities and other agencies apply a variety of principles in different parts of the system, including academic freedom, accountability, access, integrity, social inclusion and the peer review process, but there is no national commitment to education for democracy.

A striking features of the US system is the wide gap in average incomes between college graduates and the rest of the population (Tamborini 2015; *). Incomes of the bottom 50\%, mostly non-graduates, have fallen and inequality has grown since 1980 (Pew 2020; Quah 2019). Income inequalities between graduates and non-graduates are reflected in divergent political perspectives and voting patterns, particularly among white citizens (Harris 2018, Parker 2019, Pew 2016), so that universities are a factor in the wide social divisions within the American system.

America's elite universities also have a powerful influence over academic institutions and practices throughout the world, attracting scholars, students and funds as well as influencing policies and priorities, so they have a major responsibility to address issues of civic engagement and democracy.

\section{System-level challenges}

Every system of higher education can be seen as a Social Model and multiplicity of ad hoc experiments. These two contrasting examples raise challenging questions about how to foster teaching and learning for democratic civic engagement, such as:

1. What national policies and laws are best at providing it for all citizens?

2. What funding mechanisms will encourage it?

3. How can university rankings recognise and reward institutions that do it?

4. What forms of assessment, evaluation and research are best at improving its impact and effectiveness? 
These questions are equally important across Africa, Asia and Europe. * The history of different Models in Germany, Korea, Taiwan, Scandinavia, South Africa and other countries offer significant lessons. Political science can address these questions through research, policy development and advocacy to improve Models in their own country.

\section{Conclusion: Three Strategies for Civic Engagement}

Liberal democracies face existential threats. The democratic processes of challenge, scrutiny and competition for power seem inadequate to address looming problems of global heating, biodiversity loss, food insecurity, artificial intelligence, migration and more. As humanity grows by about two billion more people in just 35 years, authoritarian regimes like China may be more effective in tackling problems and offer a more attractive Model than embattled democracies. Competent authoritarians could win elections in established democracies to dismantle democratic norms and create new political models that manage citizens and suppress dissent in the name of a greater good.

In this paper I have tried to show that institutions can be seen as natural experiments and Social Models, equivalent to theories in the natural sciences. This implies that social and political sciences need to work with practitioners, policy makers and citizens to improve the ability of institutions to achieve social objectives. In democratic societies all institutions are ultimately subject to review by citizens, so that scholars have a responsibility to enable citizens to understand and use democracy as a method for solving social problems and resolving conflicts of interest. Part 2 set out some implications of the argument and outlined ways to address democratic deficits. Part 3 outlined seven levels at which higher education fosters civic engagement. Pulling the argument together, I suggest higher education could become sophisticated agencies for democracy, providing impartial, critical and accessible information and support to citizens, enabling them to govern their societies as equals.

To achieve this, I propose three strategies for democratic civic engagement: 
1. Persuade university leaders and faculty to make learning for democracy a core mission of their institution and the education system, more important than education for business, and ensure that every citizen has the confidence, knowledge, skills and values to take part in democratic decision-making as an equal.

2. Build a non-partisan alliance of academics, funders, civil society, and politicians to address democratic deficits, systematically and resolutely, as outlined in Part 2.

3. Develop robust Models of education and support for democratic civic engagement and practical politics at all levels, from admission (i.e. exclusion) criteria, course provision and access to research, to national policies and global governance, as outlined in Part 3, including outreach to citizens who support authoritarian solutions, promote demonstrably false information, or have benefited least from education and experience exclusion, disenfranchisement or marginalisation from the current political and economic system.

Democratic governments have a decisive role in preventing or managing global crises, as well as tackling national and local issues. When governments make mistakes or fail to prevent war, as in 1914, 1939, Vietnam, Central Africa, Afghanistan, Iraq, and Syria, millions suffer. The five pandemics this century (SARS (2003), H1N1 influenza (2009), MERS (2012/3), Ebola (2015) and now Covid19) show how humanity can work together on global problems, albeit unevenly. In each case there was impressive cooperation between scientists, governments, business and civil society, despite incompetence by some political leaders. These pandemics provide many lessons for how to deal with the bigger crises on the horizon as a result of unrestrained carbon dioxide emissions, unresolved social conflicts, and unbalanced geopolitics. In this context it is not enough for scholars to analyse the malaise and develop solutions that have little influence on events. Improving the ability of institutions to help citizens solve problems and meet their needs should be recognised as the central purpose of social sciences 
and higher education. A concerted effort by scholars to support citizens improving democracy as a model of government at scale would be a worthwhile experiment.

\section{Postscript:}

Drawing Mariana Mazzucato's Mission Economy (2021) I have sketched an outline of a global mission to strengthen democracy: see illustration below or download proposal here.

\section{Challenge}

Mission

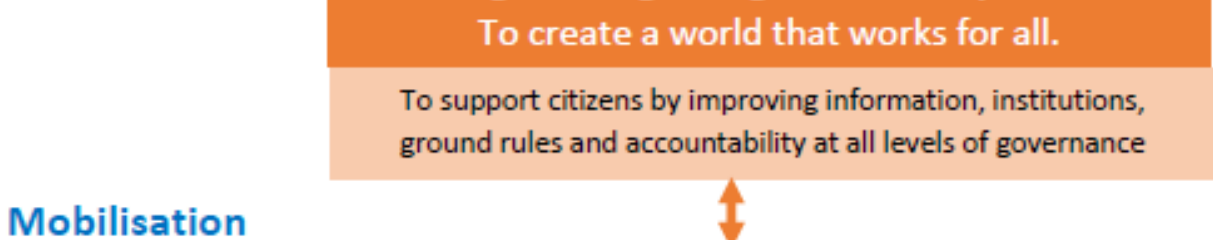

Mobilisation

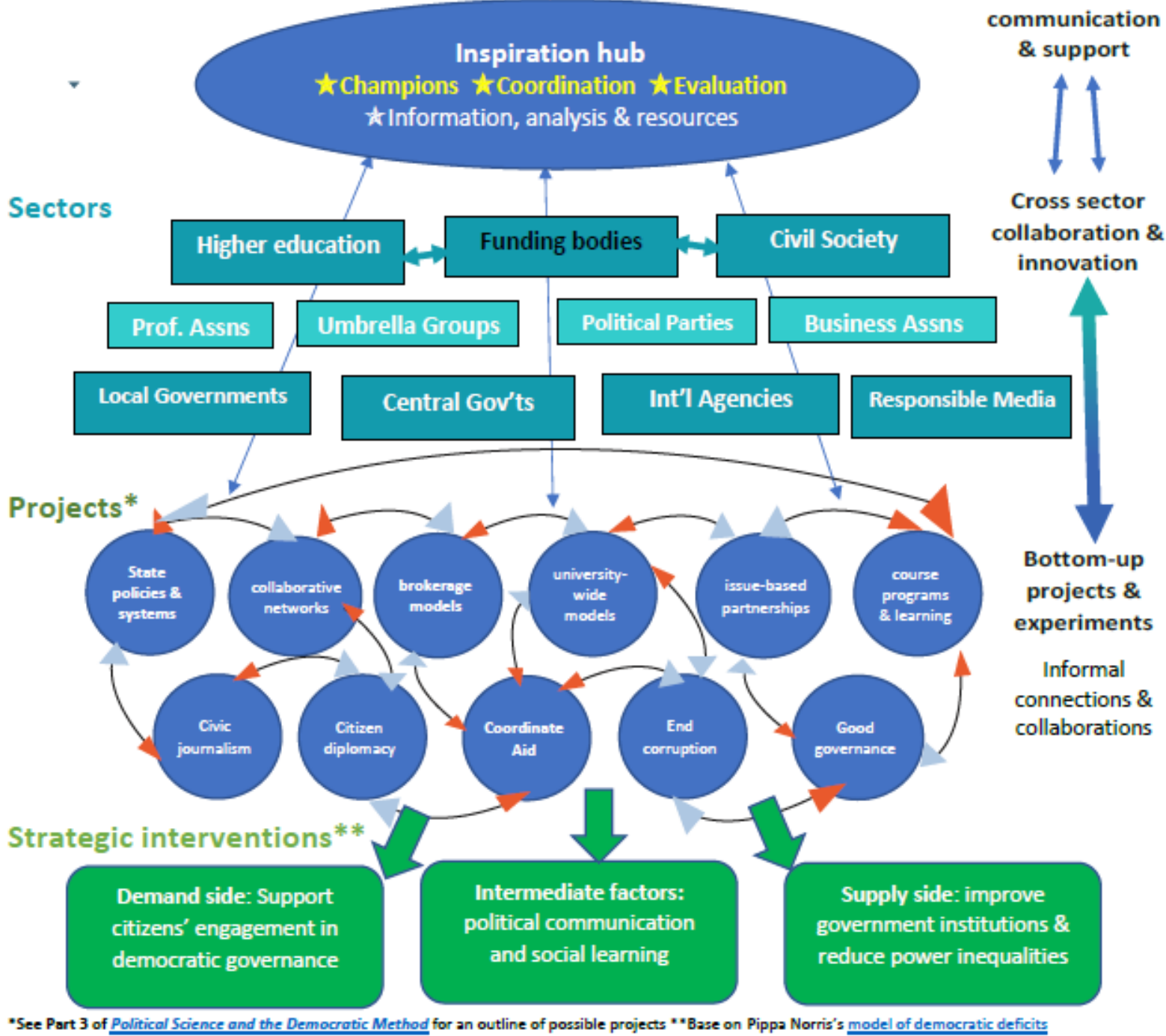

Inclusive, just $\&$ effective

Enable everyone to have an effective say in local, regional \& global governance by 2045 To create a world that works for all.

To support citizens by improving information, institutions, ground rules and accountability at all levels of governance

\section{democratic governance}




\section{Closing reflections}

Scholars have a distinguished record of studying political models and contributing to the public sphere. Woodrow Wilson drew lessons from continental Europe to advocate the study of public administration to improve government (1887) and served as president of the American Political Science Association, becoming Governor of New Jersey in 1911 and president of the United States in 1913. Wilson led on progressive reforms at home and the Covenant of the League of Nations after World War I, the first major institution of global governance. Emily Greene Balch (1867 - 1961) was an American sociologist, political scientist, economist, and leader of the women's movement for peace during and after World War I, receiving the Nobel Prize for Peace in 1946. Sarah Wambaugh (1884-1955) was an expert on the subject of plebiscites who also worked for the League of Nations secretariat and on elections in Saarland, Greece and India. John Maynard Keynes, JK Galbraith, Milton Freedman, Henry Kissinger, Noam Chomsky, Mary Warnock, Condoleezza Rice, Elizabeth Warren, Janet Yellen, Raghuram Rajan and countless scholars have played, and continue to play, decisive roles in public service. At the same time, it is important to be aware that scholars have also sought to resist democratic challenges and protect exclusive privileges. Jessica Blatt's Race and the Making of American Political Science (2018) describes how racial ideologies permeated the foundations of the discipline, which often does not give insufficient attention to its role in politics today. Scholars are also citizens with equal responsibilities for good governance and the wellbeing of society. The many current crises call for more concerted effort by scholars to support citizens developing more effective models of democratic governance at all levels.

\section{$\underline{\text { Author }}$}

Titus Alexander is an Honorary Associate Research Fellow at the Crick Centre for the Public Understanding of Politics. His latest book is Practical Politics: Lessons in Power and Democracy (2016, UCL IoE Press/Trentham) focuses on teaching democratic politics. He runs Leading Change, an advanced apprenticeship in campaigning and leadership, and is founder of Democracy Matters, an alliance for learning practical politics. He created the Charter 99 for Global Democracy campaign and Uniting Humanity, a Grundtvig trainer of trainers' programme. Publications include Discussing Democracy (2015 Crick Centre), Campaigning is OK! (2009), Learning Power (2007), Family Learning: The Foundation of Effective Education (Demos 1997), Citizenship Schools: A practical guide (2001), and Unravelling Global Apartheid: 
An overview of world politics (Polity/Blackwell's, 1996). He studied Maths, Physics and Intellectual History at the Universities of Sussex (UK) and Marburg (Germany). His thesis on the origins of Freud's pre-psychoanalytic thought is a study in the ecology of ideas. 


\section{References}

If a reference is not in the first generic list it will be in one of the categories below.

As an independent researcher I do not have access to work behind a paywall

Alexander, T (2021) Institutions as Social Theory, unpublished working paper

Alexander, T. (2016) Practical Politics: Lessons in Power and Democracy, UCL Institute of Education Press/Trentham

Alexander, T. (2001) Citizenship Schools: A practical guide, Campaign for Learning, with UNICEF UK

Alexandrowicz, Charles Henry (2017) The Law of Nations in Global History: History and theory of international law, Oxford University Press

Bastow, Simon; Dunleavy, Patrick; \& Tinkler, Jane (2014) The Impact of The Social Sciences: How academics and their research make a difference, Sage,

Bevir Mark, Ed (2010) Interpretive Political Science, SAGE

Blatt, Jessica (2018) Race and the Making of American Political Science, University of Pennsylvania Press

Cohen DK, Lindblom CE. (1975) Solving Problems of Bureaucracy: Limits on Social Science. American Behavioral Scientist. 1979; 22(5):547-560.

doi:10.1177/000276427902200509

Collins, Ben (2018) Adoption and spread of innovation in the NHS, Kings Fund, London, accessed 23-11-20

Crewe, Ivor, and King, Anthony (2013) The Blunders of Government, London: Oneworld,

Cunningham, Edward, Tony Saich, and Jessie Turiel. (2020) Understanding CCP Resilience: Surveying Chinese Public Opinion Through Time, Ash Center for Democratic Governance and Innovation, Harvard

Dean, Hartley. (2019) Social Policy. United Kingdom, Wiley

Dewy, John (1916) Democracy and Education: an introduction to the philosophy of education, MacMillan

Eder, Christina; Mochmann, Ingvill C.; Quandt, Markus, (2014) Political Trust and Disenchantment with Politics: International Perspectives, Brill

Ferguson, Niall (2017) The Square and the Tower, Penguin

Finlayson, A (2004) The Interpretive Approach in Political Science: a Symposium. The British Journal of Politics and International Relations. 2004;6(2):129-164.

doi:10.1111/j.1467-856X.2004.t01-6-00131.x

Gibbons, M (2006). Hermeneutics, Political Inquiry, and Practical Reason: An Evolving Challenge to Political Science. American Political Science Review, 100(4), 563-571. doi:10.1017/S0003055406062435

Grant, R,W., Political Theory, Political Science, and Politics. Political Theory. 2002; 30(4):577-595. doi:10.1177/0090591702030004007 
Greer, Scott L; King, Elizabeth J; Massard da Fonseca, Elize, \& Peralta-Santos, Andre (2020) The comparative politics of COVID-19: The need to understand government responses, Global Public Health, 15:9, 1413-1416, DOI: 10.1080/17441692.2020.1783340

Hall, Peter A., and Soskice, David (eds) Varieties of Capitalism: The Institutional Foundations of Comparative Advantage (2001)

Halper, Stefan \& Clark, Jonathan, Eds (2005) America Alone: The Neo-Conservatives and the Global Order Cambridge UP,

Hemp, Paul (2004) Presenteeism: At Work—But Out of It, Harvard Business Review, Oct 2004

Huntington, Samuel P. (1996). Political Order in Changing Societies. Yale University Press.

Johns Hopkins Coronavirus Resource Center: https://coronavirus.jhu.edu/region

Jouanna, Jacques (2001). Hippocrates. Baltimore, Md.: Johns Hopkins University Press

Keane, J. (2009) The Life and Death of Democracy, Simon \& Schuster

Keane, J. (2020) The New Despotism, Harvard UP

Kleiner, Art (2003) Who Really Matters: The Core Group Theory of Power, Privilege and Success, Nicholas Brealey Publishing

Langdon, Stephen H.; Gardiner, Alan H. (1920). "The Treaty of Alliance between Hattusili, King of the Hittites and the Pharaoh Ramesses II of Egypt". Journal of Egyptian Archaeology. 6 (3): 179-205. JSTOR $\underline{3853914}$

Lieven, Anatol (2012) America Right or Wrong: An Anatomy of American Nationalism, Oxford UP

Levitsky, S. \& Ziblatt, D. (2019) How Democracies Die: What History Reveals About Our Future, Viking

Lindblom, Charles E. \& Cohen, David K. (1979) Useable Knowledge: Social Sciences and Social Problem Solving, Yale

Lindblom, Charles E. \& Cohen, David K. (1979) Solving Problems of Bureaucracy: Limits on Social Science, https://doi.org/10.1177/000276427902200509

Lijphart, Arend (1971) Comparative Politics and the Comparative Method The American Political Science Review, Vol. 65, No. 3. (Sep., 1971), pp. 682-693. Stable URL:

http://links.jstor.org/sici?sici=0003-

0554\%28197109\%2965\%3A3\%3C682\%3ACPATCM\%3E2.0.CO\%3B2-I

Lora Cohen-Vogel (2019) Civic Education and the Paradox of Political Participation, Peabody Journal of Education, 94:1, 1-3, DOI: 10.1080/0161956X.2019.1553583

Lowndes, Vivien \& Roberts, Mark (2013) Why Institutions Matter: The New Institutionalism in Political Science, Macmillan International Higher Education,

Mahbubani, Kishore (2020) Has China Won? The Chinese Challenge to American Primacy, Public Affairs;

McKenna, C. and Morrison, A. (2008) Scottish Government Social Research Group, Social Science Methods Series Guide 3: Natural experiments, Scottish Government 
Michaels, David (2008) Doubt Is Their Product: How Industry's Assault on Science Threatens Your Health, OUP,

Mudde, Cas (2019) The Far Right Today, Polity

Norris, Pippa (2011; 2014) Democratic Deficit: Critical Citizens Revisited, Cambridge University Press

Norris, P. \& Inglehart, R. (2018) Cultural Backlash: Trump, Brexit, and Authoritarian Populism, Cambridge UP

Oppenheim, L. (1909). The Hague Peace Conferences of 1899 and 1907. By James Brown Scott. Baltimore: Johns Hopkins Press. 1909. 2 vols. pp. 887, 547. American Journal of International Law, 3(4), 1054-1056. doi:10.2307/2186449

Oreskes, Naomi \& Conway, Erik M. (2010) Merchants of Doubt, Bloomsbury Press, NY,

Peters, B. Guy (2019) Institutional Theory in Political Science, Fourth Edition: The New Institutionalism, Edward Elgar Publishing

Popper, Karl (1976) Unended Quest: An Intellectual Autobiography Fontana/Collins

Roger Eatwell, \& Goodwin, Matthew (2018) National Populism: The Revolt against Liberal Democracy,

Scott, JB (1909) The Hague Peace Conferences of 1899 and 1907: a Series of Lectures delivered before the Johns Hopkins University in the Year 1908. By JAMES BROWN SCOTT, Technical Delegate of the United States to the Second Peace Conference at the Hague. In two volumes. Volume I. Conferences. Volume II. Documents. (Baltimore: The Johns Hopkins Press. 1909. Pp. xiv, 887; vii, 548.), The American Historical Review, Volume 15, Issue 1, October 1909, Pages 151-153, https://doi.org/10.1086/ahr/15.1.151

Tuchman, Barbara W. (1984) The March of Folly: From Troy to Vietnam, NY: Knopf 1984,

Wilson, Woodrow (1887) “The Study of Administration" Political Science Quarterly, July 1887, reprinted by the Heritage Foundation

\section{Brokerage models}

Dobbins, Maureen; Paula Robeson; Donna Ciliska; Steve Hanna; Roy Cameron; Linda O'Mara; Kara DeCorby; Shawna Mercer (2009). "A description of a knowledge broker role implemented as part of a randomized controlled trial evaluating three knowledge translation strategies". Implementation Science. 4: 23. doi:10.1186/1748-5908-4-

23. PMC 2680804. PMID 19397820.

Hargadon, Andrew B. (2002), "Brokering knowledge: Linking learning and innovation", Research in Organizational Behavior, 24: 41-85, doi:10.1016/s0191$\underline{3085(02) 24003-4}$, ISBN 978-0762308781

von Malmborg, Fredrik (2004), "Networking for knowledge transfer: towards an understanding of local authority roles in regional industrial ecosystem management", Business Strategy and the Environment, 13 (5): 334-345, doi: $\underline{10.1002 / b s e .419}$

Lavis, John N. (2006). "Research, public policymaking, and knowledge-translation processes: Canadian efforts to build bridges". The Journal of Continuing Education in the Health Professions. 26 (1): 37-45. doi:10.1002/chp.49. PMID 16557509. 
Lomas, Jonathan (2007). "The in-between world of knowledge brokering". BMJ (Clinical Research Ed.). 334 (7585): 129

132. doi: $10.1136 / \mathrm{bmj} .39038 .593380$. AE. PMC 1779881. PMID 17235094.

Sousa, Milton (2008), "Open innovation models and the role of knowledge brokers" (PDF), Inside Knowledge Magazine, archived from the original (PDF) on 2009-1024 , retrieved 30/12/2020

McGuinness, David (2012) Knowledge Brokerage in Action in European Cities: Key Insights from Five Successful Knowledge Brokerage Initiatives, Case studies published by ICLEI, Informed Cities

Quarmby, Sarah (2018), Evidence-informed policymaking: does knowledge brokering work? LSE Blog

Verona, G.; Prandelli, E.; Sawhney, M. (2006), "Innovation and virtual environments: Towards virtual knowledge brokers", Organization Studies, 27(6): 765788 doi: $10.1177 / 0170840606061073$

Zook, Mathew A. (2004), "The knowledge brokers: venture capitalists, tacit knowledge and regional development", International Journal of Urban and Regional Research, 28 (3): 621641, CiteSeerX 10.1.1.569.4211, doi: $\underline{10.1111 / j .0309-1317.2004 .00540 . x}$

\section{Business Models}

Fielt, E. (2011). Business Service Management, Understanding Business Models, Vol. 3,

Ghezzi, Antonio (2020) How Entrepreneurs make sense of Lean Startup Approaches:

Business Models as cognitive lenses to generate fast and frugal Heuristics, Technological Forecasting and Social Change, Volume 161, 2020, 120324, https://doi.org/10.1016/j.techfore.2020.120324.

Peter Weill, Thomas W. Malone, Victoria T. D’Urso, George Herman, Stephanie Woerner, (2005) Do Some Business Models Perform Better than Others? A Study of the 1000 Largest US Firms MIT Sloan School of Management Working Paper No. MIT Center for Coordination Science Working Paper No. 226,

Nunes, M.P. and Russo, A.P. (2019), "Analysis of business models innovation - a multiple case study", Innovation \& Management Review, Vol. 16 No. 1, pp. 17-

35. https://doi.org/10.1108/INMR-11-2018-0085, Emerald Publishing

Smith, Ambrose (2016) McDonald's distribution channel \& supply chain logistics, Deakin Business School, accessed 4.10.20

\section{Civic education and pedagogy}

Campbell, David E. (2019) What Social Scientists Have Learned About Civic Education: A Review of the Literature, Peabody Journal of Education, 94:1, 3247, DOI: $\underline{10.1080 / 0161956 X .2019 .1553601}$

Guilfoile, Lisa, Delander, Brady \& Kreck, Carol (2016) Guidebook: Six Proven Practices for Effective Civic Learning, Education Commission of the States (ECS)

Kirkpatrick, Don (1993), Evaluating Training Programs: The Four Levels, 1st Edition, BerrettKoehler, $3^{\text {rd }}$ Edition 2006,

Kirkpatrick, James, \& Kirkpatrick, Wendy Kayser (2016) Kirkpatrick's Four Levels of Training Evaluation, ATD Press 
Lora Cohen-Vogel (2019) Civic Education and the Paradox of Political Participation, Peabody Journal of Education, 94:1, 1-3, DOI: $\underline{\text { 10.1080/0161956X.2019.1553583 }}$

Mayhew, K. C., Edwards, A. C. [1936] (1966). The Dewey School: The Laboratory School of the University of Chicago, 1896-1903. United States: Atherton Press.

Mayhew, Katherine Camp, and Edwards, Anna Camp The Dewey School: The Laboratory School of the University of Chicago, 1896-1903 [1936] (New Brunswick, NJ: Aldine Transactions, 2007), xiii-xiv.

Nordvall, Henrik (2009) Literature on the Folk High Schools: A Selected Bibliography, henrik.nordvall@liu.se Linköping university, Draft-version [not language-checked],

Tamborini CR, Kim C, Sakamoto A. Education and Lifetime Earnings in the United States. Demography. 2015 Aug;52(4):1383-407. doi: 10.1007/s13524-015-0407-0. PMID: 26100983; PMCID: PMC4534330.

Tamkin, P., Yarnall, J., Kerrin. M. (2002) Kirkpatrick and Beyond: A Review of Models of Training Evaluation, IES Report 392 Institute for Employment Studies (2002)

Toiviainen, Timo (1995) A Comparative Study of Nordic Residential Folk High Schools and the Highlander Folk School. Convergence, v28 n1 p5-24 1995

Torney-Purta, J., Cabrera, J. C., Roohr, K. C., Liu, O. L., \& Rios, J. A. (2015). Assessing civic competency and engagement in higher education: Research background, frameworks, and directions for next-generation assessment. ETS Research Report Series, 2015(2), 1-48.

Civic education

Joseph E. Kahne and Susan E. Sporte, "Developing Citizens: The Impact of Civic Learning Opportunities on Students' Commitment to Civic Participation," American Educational Research Journal 45[3] 738-766 (2010);

Matto, Elizabeth C., McCartney, Alison Rios Millett, Bennion, Elizabeth A., Simpson, Dick, eds (2017) Teaching Civic Engagement: From Student to Active Citizen, American Political Science Association

McCartney, Alison Rios Millett, Bennion, Elizabeth A., Simpson, Dick, eds (2013), Teaching Civic Engagement across the Disciplines, American Political Science Association

Judith Torney-Purta and Britt S. Wilkenfeld, Paths to 21st Century Competencies Through Civic Education Classrooms: An Analysis of Survey Results from Ninth-Graders (Silver Spring, MD: American Bar Association Division for Public Education and the Campaign for the Civic Mission of Schools Consortium, 2009);

Kristen C. Wilcox, "The Importance of Civic Responsibility in Higher Performing Middle Schools: An Empirical Study," Education and Urban Society 43[1] 26-41 (2011).

Scott Myers-Lipton, (2017) CHANGE: A student Guide to Social Action, Routledge, Scott Myers-Lipton, (2021) CHANGE! A Guide to Teaching Social Action, Taylor \& Francis

\section{China, Korea and Taiwan}

China Education Centre (2020) Higher Education in China, website based in Hong Kong, accessed 23.9.20, (About CEC) 
Cong, Le (2016) The difference between North and South Korea governance styles and their effects on the citizensv. 10.13140/RG.2.1.2110.3127

Creel, H. G. (1983). The Origins of Statecraft in China: The Western Chou Empire, University of Chicago Press

Elleman, Bruce A. \& Paine, S. C. M. (2019) Modern China: Continuity and Change, 1644 to the Present Second Edition, Rowman \& Littlefield

Fitzgerald, C. P. (1956) Continuity in Chinese history, Historical Studies: Australia and New Zealand, 7:26, 136-148, DOI: 10.1080/10314615608595052

Hamilton, Clive and Ohlberg, Mareike (2020) Hidden Hand: Exposing How the Chinese Communist Party is Reshaping the World, Oneworld

Nigel Inkster: The Great Decoupling: China, America and the Struggle for Technological Supremacy, Hurst Publishers, 2020

Kai Fu Lee: AI Superpowers: China, Silicon Valley, and the New World Order, Houghton Mifflin Harcourt

Lee, Thomas H.C. (2000) Education in Traditional China: A History, Brill

Mahbubani, Kishore (2020) Has China Won? The Chinese Challenge to American Primacy, Public Affairs;

Ministry of Education of the People's Republic of China (1999) Higher Education Law of the People's Republic of China, Adopted at the Fourth Session of the Standing Committee of the Ninth National People's Congress on August 29, 1998, promulgated by Order No. 7 of the President of the People's Republic of China on August 29, 1998 and effective as of January 1, 1999, accessed 20.10.20

Morrison, Wayne M. (2019) China's Economic Rise: History, Trends, Challenges, Implications for the United States, RL33534, Congressional Research Service, accessed 2.1.21

Szunomár, Á. (2020). The digital great leap forward mapping China's 21st century attempt to create a new growth model, Acta Oeconomica AOecon, 70(S), 95-115. Retrieved Jan 2, 2021, from https://akjournals.com/view/journals/032/70/S/article-p95.xml

Takashi Suzuki (2019) China's United Front Work in the Xi Jinping era - institutional developments and activities, Journal of Contemporary East Asia Studies, 8:1, 83-

98, DOI: $\underline{10.1080 / 24761028.2019 .1627714}$

Yaqing Qin, Continuity through Change: Background Knowledge and China's International Xinjiang Documentation Project at the University of British Columbia

Strategy, The Chinese Journal of International Politics, Volume 7, Issue 3, Autumn 2014, Pages 285-314, https://doi.org/10.1093/cjip/pou034

Yanjie Bian (2018), Guanxi, How China Works (China Today), Polity

World Bank (2018) China - Systematic Country Diagnostic : towards a more inclusive and sustainable development (English). Washington, D.C. : World Bank Group.

http://documents.worldbank.org/curated/en/147231519162198351/China-Systematic-

Country-Diagnostic-towards-a-more-inclusive-and-sustainable-development 


\section{Collaborative Networks / Networks}

Camarinha-Matos L.M., Afsarmanesh H. (2004) The Emerging Discipline of Collaborative Networks. In: Camarinha-Matos L.M. (eds) Virtual Enterprises and Collaborative Networks. PRO-VE 2004. IFIP International Federation for Information Processing, vol 149. Springer, Boston, MA. https://doi.org/10.1007/1-4020-8139-1_1

Camarinha-Matos L.M., Afsarmanesh H. (2006) Collaborative Networks. In: Wang K., Kovacs G.L., Wozny M., Fang M. (eds) Knowledge Enterprise: Intelligent Strategies in Product Design, Manufacturing, and Management. PROLAMAT 2006. IFIP International Federation for Information Processing, vol 207. Springer, Boston, MA . https://doi.org/10.1007/0-387$\underline{34403-94}$

Camarinha-Matos, L. M., \& Afsarmanesh, H. (2012). Taxonomy of collaborative networks forms: FInES Task Force on Collaborative Networks and SOCOLNET - Society of Collaborative Networks. In Roots and Wings, European Commission. http://www.finescluster.eu/fines/jm/Publications/Download-document/378-

FInES_Taxonomy_of_Collaborative_Networks_Forms_Final.html

Castells, Manuel (1996, second edition, 2009). The Rise of the Network Society, The Information Age: Economy, Society and Culture Vol. I. Malden, MA; Oxford, UK: Blackwell. ISBN 978-0-631-22140-1.

Castells, Manuel (1997, second edition, 2009). The Power of Identity, The Information Age: Economy, Society and Culture Vol. II. Malden, MA; Oxford, UK: Blackwell. ISBN 978-14051-0713-6.

Castells, Manuel (1998, second edition, 2010). End of Millennium, The Information Age: Economy, Society and Culture Vol. III. Malden, MA; Oxford, UK: Blackwell. ISBN 978-0631-22139-5.

Himmelman, Athur T. (2001) On Coalitions and the Transformation of Power Relations: Collaborative Betterment and Collaborative Empowerment, American Journal of Community Psychology, Vol. 29, No. 2, 2001

Fox, Jonathan (2010) Coalitions and Networks, University of California-Santa Cruz, Santa Cruz, CA, USA, in International Encyclopedia of Civil Society, Springer, New York, NY, DOI: https://doi.org/10.1007/978-0-387-93996-4

\section{Higher education}

Connell, Raewyn (2019) The Good University: What Universities Actually Do and Why It's Time for Radical Change, Zed Books

Daniels, Ronald J. (2020), University in Liberal Democracy, Association of American Law Schools Annual Meeting, Johns Hopkins University, January 3, 2020

Davies, Mark (2015) Academic freedom: a lawyer's perspective. Higher Education, 70 (6). pp. 987-1002. ISSN 0018-1560 Accessed 18 Nov 2020

Ellis, Heather (2013) 'Efficiency and Counter-Revolution: Connecting University and Civil Service Reform in the 1850s'. History of Education: Journal of the History of Education Society 42, 1, 23-44

Nelson, Adam The Global University (2012) 
Harris, Adam (2018) America Is Divided by Education: The gulf between the party identification of white voters with college degrees and those without is growing rapidly. Trump is widening it. The Atlantic, NOVEMBER 7, 2018

Lucas, C. J. (1996a). American higher education: A history. New York: St. Martins Press

(Bok, 2004; Breton and Lambert, 2003; Geiger, 2004; Priest and St John, 2006; Slaughter and Leslie, 1999). Some have argued that the autonomous university is in ruins (Delanty, 2001; Readings, 1996).

Parker, Kim (2019) The Growing Partisan Divide in Views of Higher Education, Pew Research Center, AUGUST 19, 2019

Pew Research Center (2016) A Wider Ideological Gap Between More and Less Educated Adults, APRIL 26, 2016

Sambell, K., and L. McDowell. 1998. The construction of the hidden curriculum: Messages and meanings in the assessment of student learning. Assessment and Evaluation in Higher Education 23: 391-402.

Slaughter, Sheila, and Leslie, Larry L. (1997) Academic Capitalism: Politics, Policies, and the Entrepreneurial University, John Hopkins Press

Tamborini, Christopher \& Kim, ChangHwan \& Sakamoto, Arthur. (2015). "Education and Lifetime Earnings in the United States". Demography. 52. 1383-1407. 10.1007/s13524-0150407-0.

Walters, Shirley, and Openjuru, George (2014) Knowledge, Engagement and Higher Education in Africa, in (GUNI), Global University Network for Innovation (authors), Higher Education in the World 5: Knowledge, Engagement and Higher Education: Contributing to Social Change, UNESCO/Palgrave, Paper IV.2, pp 142-152

Williams, Allan P O (2010) The history of UK business and management education, Emerald, ISBN 9781849507806

\section{University ranking}

in the Shanghai Academic Ranking of World Universities and the US News \& World Report Best Global University Ranking, 2020 CWTS Leiden Ranking, China surpassed the U.S. with the number of universities including in the ranking for the first time (204 vs.198). The University Ranking by Academic Performance 2019-2020 includes 2500 universities in the rankings: China tops the list, with 389 , followed by the US with 352 . China has dominated the QS BRICS University Rankings and the THE's Emerging Economies University Rankings, claiming seven of the top 10 spots for both rankings. China is also the most-represented nation overall and in 2017 it surpassed the U.S. with the highest number of scientific publications. (Tollefson, Jeff (2018). "China declared world's largest producer of scientific articles". Nature. 553 (7689): 390. doi: 10.1038/d41586-018-00927-4

Academic Freedom and the Law: Summary of the International Law Discussion Group meeting held at Chatham House, 8 December 2010 Eric Barendt, Emeritus Professor of Media Law, University College London; David Bentley, Associate Fellow, Chatham House

\section{$\underline{\text { Institutions }}$}

Acemoglu, Daron and Robinson, James A. (2012) Why Nations Fail: The Origins of Power, Prosperity, and Poverty, Crown Publishers US, Profile Books UK 
Thelen, Kathleen, (2004) How Institutions Evolve: The Political Economy of Skills in Germany, Britain, the United States, and Japan, Cambridge University Press

Thelen, Kathleen, (2014) Varieties of Liberalization and the New Politics of Social Solidarity. Cambridge Studies in Comparative Politics

\section{McDonalds}

Battye, Luke (2018) Why We're Loving It: The Psychology Behind the McDonald's Restaurant of the Future, BehaviouralEconomics.com, blog accessed 21 September 2020

Cunningham, Edward, Saich, Tony, \& Turiel, (2020) Understanding CCP Resilience: Surveying Chinese Public Opinion Through Time, Ash Center for Democratic Governance and Innovation, Harvard

Gregory, Lawrence (2017) McDonald's Generic Strategy \& Intensive Growth Strategies, Panmore Institute, accessed 21 September 2020

Daszkowski, Don (2019), Requirements to Open a McDonald's Franchise, The Balance, accessed 4.10.2020

Market Screener: https://www.marketscreener.com/quote/stock/MCDONALD-SCORPORATION-4833/company/

Profitworks, How McDonald's Became The Leader In The Fast Food Industry , accessed 21 September 2020

Thompson, Andrew (2019), McDonald's Organizational Structure \& Its Characteristics - An Analysis, Panmore Institute, accessed 21 September 2020

\section{$\underline{\text { Research Methods }}$}

Bergold, Jarg; Thomas, Stefan (2012) Participatory Research Methods: A Methodological Approach in Motionv. Forum Qualitative Sozialforschung / Forum: Qualitative Social Research, [S.1.], v. 13, n. 1, jan. 2012. ISSN 1438-5627. Accessed: 18 Nov. 2020. doi:http://dx.doi.org/10.17169/fqs-13.1.1801

Chambers, R. (1983) Rural Development: Putting the last first, Longman, Harlow.

Chambers, R. (1997) Whose Reality Counts? Putting the first last, Intermediate Technology Publications, London.

Reason, Peter \& Bradbury, Hilary (Eds.) (2008b). The Sage handbook of action research. Participative Inquiry and Practice (2nd ed.). London: Sage.

\section{Political economy}

Mazzucato, Mariana (2021) Mission Economy: A Moonshot Guide to Changing Capitalism, Allen Lane/Penguin

Huntington, Samuel P. (1996). Political Order in Changing Societies. Yale University Press.

Quah, Danny (2019) The US is, indeed, the exceptional nation: Income dynamics in the bottom 50\%, Lee Kuan Yew School of Public Policy, January 2019, accessed 20.10.20 Pew Research Center (2020), Trends in income and wealth inequality, by Juliana Menasce, Horowitz, Ruth Igielnik And Rakesh Kochhar, accessed 20.10.20 